\title{
Bürokrasi-Siyaset İlişkisi Bağlamında Başkanlık ve Cumhurbaşkanlığı Hükümet Sistemlerinin İncelenmesi
}

\author{
Murat AKÇAKAYA*
}

Kübra İLHAN**

Geliş Tarihi (Received): 16.09.2021 - Kabul Tarihi (Accepted): 01.11.2021

\section{$\ddot{\mathbf{O z}}$}

Devletler kamu hizmetlerini, kamu görevlilerinin faaliyette bulunduğu bürokrasi ve siyasi otoritenin görev yaptı̆ğ siyasi sistem ile sunmaktadır. Siyasi otorite devlet yönetimine dair kararları alırken, bürokrasi ise bu karaları hayata geçirmektedir. Siyasi otorite ve bürokrasi, kamu hizmeti sunmak adına var olmaktadır. Etkin bir kamu yönetimi için her iki aktörün uyum içinde faaliyet göstermesi gerekmektedir. Bürokrasi ve siyasi otoriteye farklı rollerin yüklendiği birçok yaklaşım olmasına rağmen bu yaklaşımlar arasındaki ortak nokta ise bürokrasi ile siyaset arasında keskin bir çizginin çizilemeyecek olmasıdır. Bürokrasinin edilgen konumda olduğu ve siyasi otoritenin kamu yönetimi üzerinde etkin bir politika uyguladığı idari yapılar olduğu gibi bunun tam aksi hali de görülmektedir. Her iki aktörün yönetsel süreçte etkin veya edilgen bir yapıya sahip olması hükümet sistemlerine göre değişiklik göstermektedir. Çalı̧̧ada, hükümet sistemleri arasında birbirine olan benzerliği ve farklılığı üzerinde pek çok araştırma ve tartışmaların yapıldığı Başkanlık Sistemi ile Türk tipi Başkanlık Sistemi olarak nitelendirilen Cumhurbaşkanlığı Hükümet Sistemi ele alınmıştır. Çalışmada, güçlü bir yürütme sisteminin hâkim olduğu her iki hükümet sisteminde siyaset-bürokrasi ilişkisi incelenerek, siyasi otoritenin bürokrasi üzerindeki etkisini değerlendirmek amaçlanmaktadır. Bu doğrultuda çalışmanın ilk bölümünde siyaset ve bürokrasi kavramları; ikinci bölümde Başkanlık ve Cumhurbaşkanlığı Hükümet Sistemlerinin genel özellikleri; son bölümde ise Başkanlık ve Cumhurbaşkanlığı Hükümet Sistemlerinde siyaset-bürokrasi ilişkisi ele alınmaktadır.

Anahtar Kelimeler: Bürokrasi, Siyaset, Başkanlık Sistemi, Cumhurbaşkanlığı Hükümet Sistemi

\section{Investigation of Presidency and Presidency Government Systems in the Context of Bureaucracy-Politics Relationship}

\begin{abstract}
States provide public services with the bureaucracy in which public officials operate and the political system in which the political authority works. The political authority makes decisions about state administration, while the bureaucracy makes these decisions. Political authority and bureaucracy exist to provide public service. For an effective public administration, both actors must operate in harmony. Although there are many approaches in which different roles are attributed to bureaucracy and political authority, the common point between these approaches is that a sharp line cannot be drawn between bureaucracy and politics. Just as there are administrative structures in which the bureaucracy is in a passive position and the political authority implements an effective policy on public administration, the opposite is also seen. The fact that both actors have an active or passive structure in the administrative process varies according to government systems. In the study, the Presidential System, where many researches and discussions are made on the similarity and difference between the government systems, and the Presidential Government System, which is described as the Turkish type Presidential System, are discussed. In this study, it is aimed to evaluate the effect of political authority on bureaucracy by examining the relationship between politics and bureaucracy in both government systems dominated by a strong executive system. In this direction, in the first part of the study, the concepts of politics and bureaucracy; in the second part, general characteristics of Presidential and Presidential Government Systems; In the last part, the relationship between politics and bureaucracy in the Presidency and Presidential Government Systems is discussed.
\end{abstract}

Keywords: Bureaucracy, Politics, Presidential System, Presidential Government System

\footnotetext{
* Prof. Dr., Hacı Bayram Veli Üniversitesi I.I.I.B.F., Siyaset Bilimi ve Kamu Yönetimi Bölümü, akcakaya76@hotmail.com., ORCID ID: https://orcid.org/0000-0003-0976-9054

** Doktora Öğrencisi, Hacı Bayram Veli Üniversitesi, Lisansüstü Eğitim Enstitüsü, kubra.ilhan@hbv.edu.tr. ORCID ID: https://orcid.org/0000-0003-4665-9794
} 


\section{Giriş}

Devlet yönetiminin etkin duruma gelmesi ve demokratik değerlerin önem arz etmesi ile birlikte bürokrasinin konumu tartışılmaya başlanmıştır. Bürokrasinin konumunu ise siyasi otorite belirlemektedir. Bu doğrultuda kamu yönetiminin siyaset-bürokrasi ilişkisi ekseninde şekillendiği söylenebilir. Siyasi otoritenin bürokrasi üzerindeki etkisi, bürokrasinin işleyişini önemli düzeyde etkilemekte ve bürokratik sorunların temelinde siyasallaşmış bürokratik yapıların olduğu görülmektedir. Bu nedenle etkin bir kamu yönetimi için uyumlu ve dengeli siyaset-bürokrasi ilişkisinin varlığı önem arz etmektedir. Bürokrasinin siyaset karşısında kullanmış olduğu güç kaynakları olduğu gibi siyasi otoritenin de güç kaynakları bulunmaktadır. Son y1llarda kamu yönetiminde yaşanan değişim ve dönüşüm neticesinde bürokrasinin sahip olduğu güç kaynaklarında zayıflama görülmesine rağmen bu durum hükümet sistemleri arasında farklılık göstermektedir. Devletlerin siyasi ve mali rejimlerinde farklılıklar görüldüğü kadar, siyaset-bürokrasi ilişkilerinde de farklı özellikler bulunmaktadır. Bu farklılığın en temel nedeni olarak, benimsenen hükümet sistemi gösterilmektedir. Bürokrasinin güçlü olması hatta bürokratik vesayete yol açabilecek niteliklerin bulunuyor olması uygulanan hükümet sistemi ile yakından ilgilidir. Aynı şekilde siyasi otoritenin bürokrasi üzerinde etkin rol oynaması, bürokrasinin seçilmiş siyasi otoritenin gölgesinde kalması da sahip olunan hükümet sisteminden kaynaklanmaktadır. Çünkü ülkede uygulanan hükümet sisteminin siyasi otorite ve bürokrasiye atfetmiş olduğu roller neticesinde bürokrasi-siyaset ilişkisinin özü oluşmaktadır.

Hükümet sistemleri temelde Parlamenter ve Başkanlık Sistemleri üzerinde şekillenmektedir. Türkiye'ye özgü olarak hazırlanmış Cumhurbaşkanlığı Hükümet Sistemi, sert kuvvetler ayrılığına dayanması ve güçlü bir yürütme organına sahip olması nedeniyle Başkanlık Sistemi ile benzerlik göstermekte ve türevi olarak nitelendirilmektedir Benzer niteliklere sahip olan Başkanlık Sistemi ile Cumhurbaşkanlığı Hükümet Sistemi, çalışmanın temelini oluşturmaktadır. Çalışmada, hükümet sistemlerine göre siyaset-bürokrasi ilişkisinde farklılıkların olduğu belirtilmesi ile birlikte benzer özellikleri taşıyan iki hükümet sistemindeki siyaset-bürokrasi ilişkisi ele alınarak, genel bir mukayese yapılması amaçlanmıştır. Bu doğrultuda çalışmanın ilk bölümünde öncelikle bürokrasi ve siyaset kavramları ele alınmakta ve sonrasında siyaset-bürokrasi ilişkisi değerlendirilmektedir. Çalışmanın ikinci bölümünde, çalışmanın temelini oluşturan Başkanlık ve Cumhurbaşkanlığı Hükümet Sistemlerinin temel özellikleri ele alınarak, sistemler genel hatlarıyla incelenmektedir. Üçüncü bölümde ise öncelikle Başkanlık Sisteminin en iyi şekilde uygulandığı ABD özelinde siyaset-bürokrasi ilişkisi incelenerek, mevcut kamu personel yapısı, Başkanın bürokrasi üzerindeki etkisi ve 
kontrolü, bürokrasinin siyasi otorite tarafından denetimi, üst düzey kamu görevlilerinin ve federal düzeyde atama usulleri ele alınmaktadır. Üçüncü bölümün ikinci alt başlığında ise Cumhurbaşkanlığı Hükümet Sisteminde siyaset-bürokrasi ilişkisi ele alınarak, yeni sistem öncesinde bürokrasinin konumu, yeni sistemle birlikte bürokrasinin dönüşümü, etkin bürokratik yap1 için öngörülen düzenlemeler ve zihniyet dönüşümü, Cumhurbaşkanının bürokrasi üzerindeki etkisi ve denetimi, üst düzey kamu görevlilerinin atama usulü, yeni sistemle birlikte değişen siyaset-bürokrasi ilişkisine dair yapılan değerlendirmelere yer verilmektedir.

\section{Bürokrasi ve Siyaset}

\subsection{Bürokrasi}

Bürokrasi kavramı Fransa kaynaklı olup, ilk kez 1745 yılında Fransız fizyokrat iktisatçı Vincent de Gournay tarafından kullanılmıştır (Kabaklı, 2017, s.9). Bürokrasi kavramının "bureau” kavramından geldiği ve bureau kavramının da "koyu renkli kumaşla örtülmüş yazı masası" anlamına gelen "bure" kavramına işaret ettiği belirtilmiştir. 18. Yüzyılda bureau kavramının memurların çalıştığı devlet dairesi veya büro şeklinde kullanıldığı ifade edilmiştir. Bürokrasi idari, siyasi ve sosyal yönleri bulunan geniş çaplı bir kavramdır. Bureau kavramına atfedilen anlam ile memurların toplum üzerinde artan etkisi ifade edilmeye çalışılmıştır. Bürokrasi siyasal, yönetsel ve sosyal açıdan incelenebilen geniş çaplı bir kavramdır. Bürokrasinin farklı anlamları olmasındaki en büyük etmen olarak, devletin ve toplumun geçirdiği kademeleri ortaya koyduğu gibi onların performansını, fonksiyonunu ve örgütsel hayatın farklı yönlerini de ifade etmektedir (Eryılmaz, 2013, s.19). Bürokratik yönetim görev alanı net bir şekilde belirtildiği, yürütülecek faaliyetlerin planlandığı, bütün işlemlerin yazılı olduğu, denetime dayanan ve hiyerarşiyi öngören bir yapıdadır (Çukurçayır, 2009, s.32).

Bürokrasi kavramının dört farklı anlam içerdiği belirtilmektedir. Bu dört anlamdan ilki negatif bir anlam içeren kırtasiyecilik anlamıdır. İkinci anlamı kamu mal ve hizmetlerini üretimi için kurulmuş dairelerdir. Üçüncü anlamı siyaset otoritenin vermiş olduğu kararları uygulayan memurlardır. Dördüncü anlamı ise bürokrasi bir örgüt, işleyiş ve örgütlenme şeklidir ve dördüncü anlam, Weberyen bürokrasi kuramı olarak da ifade edilmektedir (Akçakaya, 2016, s.277).

Bürokrasinin tek ve en iyi yol olarak ifade edilmesinde, her yerde ve vakitte kabul görebilecek yönetim ilkelerinin ortaya konulabilmesi varsayımı bulunmaktadır. Böylece klasik 
kamu yönetimi anlayışını ve bürokrasiyi evrensel yönetim ilkelerine taşımaktadır (Yıldırım, 2010, s.708). Örgütlenme ve yönetim şekli olarak ifade edilen bürokrasinin en belirgin özelliği büyüklüktür. Yüzlerce insanın bir otoriteye tabi olarak, belli bir amacı gerçekleştirmek için farklı faaliyetlere girişimi neticesinde yüz yüze iletişim imkânsız hale gelmektedir. Bu nedenle yazılı iletişim yolu tercih edilmektedir. Yazılı iletişim ile bürokratik ilişkiler anonim bir niteliğe sahip olmaktadır. Böylece çok sayıda personelden oluşan geniş çaplı grupların teşkilatlanmasında ve idaresinde belli başı şartlar yüklenerek biçimler oluşmaktadır. $\mathrm{Bu}$ biçimler uzmanlaşma, hiyerarşi, iş bölümü, planlama şeklinde sıralanmış ve böylece geniş grupların disiplin içerisinde yönetilebileceği ifade edilmiştir (Ergun ve Polatoğlu, 1992, s.45).

Bürokrasi, bilhassa 21.yüzyıl toplumları için büyük bir kaldıraç niteliğinde olmuştur. Ülkelerin gelişmişlik düzeyleri, bürokratik örgütlenmede hâkim olan düzey tespit edilerek ortaya konulmuştur. Azgelişmiş ülkelerde yürütülen idari reformlar, devletin bürokratik yapılanışını sağlamak olarak ifade edilen kalkınma idaresi oluşturmaya yönelik olmuştur. 21.yüzyıla doğru gelişmiş ve azgelişmiş ülkelerde durum değişerek bürokrasi, merkeziyetçi yönetim anlayışının biçimsel yapısı olarak tanımlanmaya başlanmıştır. Bürokratik yapılanma ve anlayış, gelişimin ve demokrasinin başat engeli olarak kabul görmüştür (Kalağan, 2009, s.93).

Bürokratların yönetimi olarak nitelendirilen bürokrasiyi bir yönetim biçimi şeklinde ele alan ve bürokrasiye yepyeni bir boyut getiren isim Max Weber' dir. Weber, bürokrasiyi “Geniş bir alana yayılmış toplumsal fiil ve hareketlerin, rasyonel ve objektif esaslara uygun bir şekilde düzenlenmesi sürecidir” şeklinde tanımlamıştır (Tortop vd., 2012, s.412).

Weber, bürokrasinin kurallar ekseninde oluşan bir faaliyet alanı olduğunu belirtmiştir. Aynı zamanda bürokrasinin uzmanlaşmış fonksiyonlara sahip daimî bir yapı olduğunu ifade etmiştir. Personel teşkilatının hiyerarşiye dayandığı ve bu yapı içinde görev ve yetki sahalarının net bir şekilde ortaya konulduğunu belirtmiştir. Weber'in ifade ettiği bürokratik yapıda personel, görev niteliklerine uygun bir şekilde ve atama yolu ile göreve gelmekte ve liyakat esasına göre yükseltilmektedir (Çevik, 2001, ss. 48-49).

Weber, bürokrasiyi toplum ile iktidar ilişkisini otorite kavramı üzerinden açıklamaktadır. Bu noktada otorite ile güç kavramını birbirinden ayırarak işe başlamaktadır. Eğer bir kişi, sosyal ilişkide başkalarının engellemelerine rağmen kendi iradesini sağlayabiliyorsa burada güç kavramının varlığını ifade etmektedir. Böylece bu kişi de güce sahip olmaktadır. Gücün özel durumu ise otoritedir. Eğer bir emir, başkasının itaat etmesini 
sağlıyorsa, bu otoritedir. Otorite meşruluğa dayanmakta, meşruluk ise bir inanç temeline oluşmaktadır. İnanç kavramı ise emirleri doğru kabul edilerek, itaat edilmesi gerekliliğini ifade etmektedir (Akçakaya, 2016, s.678). Weber, siyasi dünyada yönetenlerin emirlerine itaat edilmesini ele alarak, bunun nedenlerini araştırmıştır. Bu araştırma sürecinde tarihi ve sosyal gelişmeleri göz ardı etmemiş ve bu otoriteyi açıklamıştır. Weber, otoritenin üç sarf tipini ileri sürmüştür. $\mathrm{Bu}$ türleri; geleneksel otorite, karizmatik otorite ve ussal otorite şeklinde sıralamıştır. Weber her otorite tipi için otoriteye itaat edenlerin itaat etme nedenleri ve otoritenin meşruluğuna yönelik fikri ortaya koymuştur. Geleneksel otoritede itaat edenler, geleneklerin kutsal olarak algılanması nedeniyle emirlere geleneklere uygun olduğu düzeyde uyarlar. Karizmatik otoritede otorite sahibinin olağanüstü niteliklere sahip olduğu inanılır ve böylece diğer insanlardan farklı olduğu düşünülmektedir. Otoriteye itaat edenler bu düşünce ekseninde otorite sahibinin meşruluğunu da buraya dayandırmaktadırlar. Ussal otorite tipinde ise itaat edenler, emirlerin hukuki ve akli düzeyde olduğu müddetçe uyarlar. Yasalara uygun bir şekilde otorite elde eden iktidara olan inanç, tamamen rasyonel kritere uygun kurallarla mümkündür (Durgun, 1992, s.137). Weber'in ifade etmiş olduğu ussal otorite, 20. yüzyılın başlarında Avrupa devletlerinde hâkim olmaya başlayan hukuk devleti anlayışı ekseninde yönetenyönetilen ilişkisinin yalnızca kanunları dayandığı bir devlet sistemidir (Öztekin, 2005, s.272).

Weber'e göre bürokrasi kaçınılmaz olarak varlığını korumakta ve gelecekte de var olacaktır. Weber, gelecekte bürokrasinin varlığını sürdüreceğini ancak gelecekte oluşacak düzenin bugünün kapitalist düzenine göre daha baskıcı bir yapıya sahip olacağını belirtmiştir. $\mathrm{Bu}$ nedenle bürokrasinin kurumsal niteliklerinde bazı değişikliklerin yaşanacağını da vurgulamıştır. Weber, küçük ölçekte örgütlenmelere dönüş ile bürokrasinin etkisinden büyük ölçüde kurtulabileceğini belirtmiştir (Özer, 2013, s.47).

Weber'in ileri sürmüş olduğu bürokrasi kuramına yönelik eleştiriler yapılmıştır. Özellikle Weber'in vurgulamış olduğu “İdeal Tip” kavramının, bütün değer hükümlerinden arınmış bir kavram olarak ifade edilmesine rağmen değer hükümlerini bünyesini taşıdığı belirtilmiştir. Aynı zamanda Weber'in iki hususta da yanılgıya düştüğü ifade edilmiştir. Bunlardan birincisi, personelin amirlerinden aldıkları emirleri bir robot gibi yerine getirmediğini; emirleri kabul edebileceği gibi reddetme ve değiştirme gibi yönleri de seçebileceğidir. İkinci yanılgı ise emirlerin ve kararların daima yukarıdan geldiği yönündedir. Alt kademelerin de üst makamlara emir verebileceği belirtilmiştir (Tortop vd., 2012, ss.431432). 
Bürokrasi bazı yazarlar tarafından olumsuz bir kavram olarak ele alınmıştır. Bürokrasi işlerin ağır yürütülmesi, verimsizlik, gücü kötüye kullanma, hantallık gibi kavramları bünyesinde bulunduran bir anlamı olduğu yönünde fikirler öne sürülmüştür. Fransız sosyolog Frederic Le Play, bürokrasiyi otoritenin az sayıdaki memurlara teslim edilmesi ve işleri zorlaştırma olarak tanımlamıştır (Eryılmaz, 2013, s.22). Bürokrasi kavramına yönelik yapılan olumsuz değerlendirmelerin yalnızca Amerika'da ve diğer demokrat ülkelerde görülen bir olay değildir. Otoriter ülkelerde dahi bürokrasi ve bürokrat kavramları olumlu bir anlam içermemektedir. Bürokrasinin kusurlu bir yapıya olduğu yönünde genel bir fikir hâkimdir. Ancak bürokrasinin tam ve net bir biçimde tarifini yapma konusunda yetersiz kalındığ da görülmektedir (Mises, 2018, ss. 17-18).

Modern yönetim anlayışı savunucuları bürokrasiyi günah keçisi ilan ederek, bürokrasiye karşı durmuşlardır. Weber'in ileri sürmüş olduğu bürokratik yönetim anlayışının başarılı olmadığını ileri sürerek, kendilerine bu alanda yeni bir alan açmaya gayret göstermiş ve yepyeni bir dil geliştirmişlerdir. Bu dil oldukça iddialı ve merak uyandıran bir türde olmuştur. Devleti en baştan inşa edecek kadar iddialı olan bu anlayışın başarısını zaman gösterecektir. Weber’i eleştirenlerin, onun ideal zihinsel yapıyı barındıran bürokrasinin realitede bulunmadığını ve bunun bir ütopya olduğunu söylediğini de göz önünde bulundurması gerekmektedir (Özer, 2013, s.47). Bürokrasinin mevcudiyeti, bağımsız toplum ve demokratik yapılanmanın tehdit altında bulunduğunu tek başına göstermez. Bu durum mümkün olsaydı, bürokrasinin vazgeçilemez olduğu göz önünde tutulduğunda, bu değerlerin korunması da imkânsız olurdu. Bir yönetsel araca sahip olmayan hiçbir ülke bulunmamaktadır. 21. yüzyılda ileri düzeyde kompleks sanayi toplumlarında, bürokrasi gerekli bir yapı olarak görülmektedir. Bürokrasinin bağımsız toplum ve demokrasi adına tehlike arz etmesi için verimsiz bir yapıda faaliyet göstermesi, siyasal erkin koyduğu kurallardan bağımsız hareket etmesi, kamuoyuna açıklaması gereken bilgileri saklıyor olması ve halk iradesinin farklı kurumların işleyişini engellemesi gerekmektedir. Bu etmenler bulunmadığ sürece bürokrasinin bağımsız toplum ve demokrasiye herhangi bir zararının bulunmayacağı yönünde genel bir düşünce vardır. Ayrıca bürokrasinin kendi sorumluluk alanlarının dışına çıkmaması, sorumlu davranması ve bu yapının korunması için devletin yürütme, yasama ve yargı erklerinin önemli görevleri bulunmaktadır (Ergun, 1997, ss.12-13). 


\subsection{Siyaset}

Siyaset kavramı şu şekilde tanımlanmıştır: "Devlet işlerini düzenleme ve yürütme sanatıyla ilgili özel görüş veya anlayış". Tanımda yer alan özel oluş, nesnel olmayışı ifade etmektedir. Devlete dair ileri sürülen görüşler, sosyal yapının özel alanlarına kısıtlanmayarak genel anlam içerir. Siyaset kavramı Arapça kökenli olup, aynı kökten gelen "seyis" kelimesi Türkçe, İngilizce ve Fransızcada kullanılmaktadır. Siyaset kelimesi at bakımı ve terbiyesi anlamına gelmektedir. İbn Mukaffa, Farabi, Mesudi, İbn Teymiyye gibi düşünürler eserlerinde siyaset kavramını, devlet işlerine yönelik esaslar ekseninde tartışılmış ve siyaset, iktidarın şekli ve iktidarı elinde bulunduranın faaliyetleri çerçevesinde incelenmiştir (Kaya, 2014, s.228). Siyaset, insanlık tarihinin en eski etkinliklerinden biridir. İnsanların bir arada ve gruplar halinde yaşamaya başlamalarıyla birlikte meydana gelen toplumları idaresini yapmak adına yeni yöntemlerin belirlenme ihtiyacı doğmuştur. En sıradan ve yalın başlangıçlardan, modern yönetimin yapıları ve kurumları gelişmiştir. Yönetim alanında görülen gelişim her ne kadar fazla olsa da avcı-toplayıcı toplulukların yönetiminde kullanılan birçok konu günümüz siyasetinde de mevcuttur (Ball ve Peters, 2007, s.3). Siyaset, yönetim biliminde ise politikalar, kararlar, yöntemler, araçlar, kanunlar, değerler ve sorumluluk gibi hususlarla alakadar olan memurun evreni olarak tanımlanmaktadır. Yani kamu yönetiminde siyaset, kamu hizmetlerinin yürütülmesinde kullanılan yol ve yöntem olarak görülmektedir (Gökçe vd., 2002, s. 48).

"Siyaset nedir?" sorusuna yönelik birçok farklı yanıtlar verilmektedir. Bu soruya verilen cevaplar analiz edildiği vakit, cevapların iki farklı ve zıt fikir etrafından toplandığı ve siyaset kavramına dair yapılan tanımların birbirinden farklı iki ayrı yönünü gösterdiği tespit edilmiştir. Bir anlayışa göre siyaset, toplumda yaşayan insanlar arasında bir çatışma, kavga ve mücadele halidir. İnsanların sosyo-ekonomik hali ve yaradılışları ile farklı düşüncelere ve menfaatleri bulunmaktadır. İnsanların aralarındaki fikir, menfaat ve psikolojik eğilimlerin ayrı olması sonucunda ortaya çıkan çatışma siyasetin varlık nedenini sağlar. Bu çatışmanın asıl konusu toplumdaki değerlerin paylaşılması iken, asıl hedefi ise iktidarın ele geçirilmesidir. Bu görüşe zıt olan bir diğer siyaset tanımlamasında ise siyasetin amacı toplumda bütünlüğü oluşturmak, kişisel menfaatlere karşı durarak genel faydayı ve insanlar için ortak iyiliği sağlamak olduğu ifade edilmiştir. Bu ikinci görüş, siyasetin herkes için yararı bulunan bir toplum düzeni kurma gayreti taşıdığını belirterek, idealist ve bir bakıma ütopik bir anlayış tarzına sahip olduğu görülmektedir. Siyaset kavramının genel anlamda karakteristik unsurları şu şekilde sıralanabilir: Siyaset, zaman ve mekân açısından evrensel ve süreklidir. Siyasetin özünde toplumdaki değerlerin paylaşımına dair bir fikir ve menfaat çatışması ve bir iktidar 
mücadelesi bulunmaktadır. Siyaset yalnızca bir mücadele değil, ayrıca bir uzlaşmadır. Siyaset, insanların yaşamlarını yakından etkileyen ve ilgilendiren bir yapıdadır (Kapani, 2020, ss.2327).

Siyaset kavramının, birden fazla kabul edilebilir veya doğru tanımlaması bulunmaktadır. Bu nedenle özü açısından tartışmalı bir kavram olduğu ifade edilmektedir. Siyaset kavramına yönelik ifade edilen farklı fikirler, aynı kavrama dair rakip görüşlerden ibarettir. Siyaset kavramına dair ileri sürülen rakip veya alternatif görüşler olsa da siyaseti tanımlamada kullanılan iki geniş yaklaşım bulunmaktadır. İlk yaklaşım, siyaseti bir alan veya konumla ilişkilendirerek, eylemin siyaset haline gelmesi ve oluştuğu konum ile alakalı olarak ele alınmasını sağlamaktadır. İkinci yaklaşım ise siyaseti bir süreç veya mekanizma olarak ele alarak, siyasi eylemleri bütün sosyal şart ve çevrelerden etkilendiğini ileri sürmektedir. Bu iki geniş yaklaşım, siyaset kavramına alternatif tanımlar oluşturarak birçok ekolün oluşmasında etkili olmuştur (Heywood, 2016, s. 25). Modern siyasetin kurucusu olarak kabul gören Machiavelli, siyaseti güç ve iktidar kavramları çerçevesinde ele almaktadır. Machiavelli'nin "insanlar ya kazanılmalı ya da kökleri kazınmalıdır" ifadesi, siyaseti şiddet ve savaş ile ilişkilendirdiğini ortaya koymaktadır. Siyaseti, şiddet ve güç merkezi olarak kabul eden modern siyaset anlayışına karşı çıkan Hannah Arendt ise siyasetin şiddet ile değil, sözcükler ve ikna yolu anlamına geldiğini savunmuştur. Max Weber'e göre siyaset, devletlerarasında ya da bir devlette bulunan gruplar arasında iktidar paylaşımı ve bu paylaşımda etkin olmak adına yürütülen çabadır. Farabi ise siyaseti özel ve genel anlamı olduğunu belirtmiştir. Siyasal toplumun yönetimi genel anlamda siyaset iken, topluluğu gerçek mutluluğa eriştirecek yapıda düzenleme ise özel anlamda siyasettir. Farabi siyaset kavramını ele alırken toplum, fazilet ve saadet kavramlarını öne sürmektedir. Saadetin sağlanması siyaset ilmine ve topluma bağlı olduğunu belirtirken, saadeti elde etme sürecinde nelerin aracı olacağını siyaset ilminin öğreteceğini ifade etmektedir. Siyaseti devlet, mülk ve asabiyet kavramları üzerinden ele alan İbn Haldun, toplumsal yaşamın düzeni için siyasetin gerekli bir kurum olduğunu belirtmiştir (Özer, 2018, ss. 32-33).

Siyaset kendine has bir dil ile bireylerin düşüncelerini etkilemek, fikir sahibi kılmak ve nihayetinde bireyleri taraftarlar arasına almak gayesi taşımaktadır. Siyaset bu açıdan ele alındığı vakit problem çözme sanatı olmaktan ziyade, yönlendirme niteliği dikkat çekmektedir. Siyaset, kitleleri yönlendirme ve ikna etme becerisi olan önemli bir sanattır. Siyaset belli bir bakış açısından yola çıkarak toplumu idare etmek ve bunun için bir örgüt oluşturmak şeklinde ifade edildiğinde düşünce ve eğilimlerin de taşıyıcısı konumunda olmaktadır. Siyaset, teşkilatta 
verilecek kararlara ve uygulanacak faaliyetlere yön vermek için konulmuş kurallar olarak da kavramsallaştırılmaktadır (Akyüz, 2009, s.95).

Siyaset yalnızca bir insana yönelik değil, insanları ilgilendiren bir alandır. $\mathrm{Bu}$ doğrultuda siyasetin ilişki içerisinden doğan bir alan olduğu söylenmektedir. Toplum bir ilişki kümesini oluşturmaktadır. Siyaset de bu ilişki kümesi içinde yer almakta ve belli nitelikleri barındıran ilişkileri kapsamaktadır. Böylece siyaset, kendine özgü olanı tüm toplumsal ilişkiler içinde ortaya çıkarabilme olarak tanımlanmaktadır. Toplumda bulunan her türlü değer ve varlık kavramı, siyaseti içermez. Siyasetin kendine has tarafının ortaya çıkabilmesi için bu değer ve varlıkların meşru otoriteye dayanması gerekmektedir (Oktay, 2009, ss. 6-7). Siyasetin kaynağı, bireylerin farklılıklarına dayanmaktadır. Bireylerin arasında doğan farklılıklar neticesinde bazı anlaşmazlıklar ortaya çıkmaktadır. Bu anlaşmazlıkların çözümü ise siyasetin alanına girmektedir. Şiddeti içine almayan bir siyaset hâkimse, bu anlaşmazlıklar barışçıl yollarla çözüme kavuşturulmaktadır. Bireyler arasındaki farklılıklara dayanan siyasetin, her zaman ve mekânda karşılaşılan evrensel bir fenomen olduğu da söylenmektedir. İnsanların yaşamları çok farklı yapılara sahip olan bir bütünü ifade etmektedir. Farklı yapılar olsa da siyasi, sosyal, iktisadi açıdan kesin olarak net bir ayrımın yapılması mümkün değildir. Siyaset de bu aşamada ortaya çıkan ve toplumsal yapı içinde meydana gelen bir olgudur (Yayla, 1998, ss.3-4).

\subsection{Bürokrasi ve Siyaset İlişkisi}

Bürokrasi ve siyaset arasındaki ilişki çok yakın bir ilişkidir. Bürokrasi ile siyaset arasına kesin bir çizgi çizmek imkansızdır. Bürokrasi ve siyaset birbirinin içine geçmiş yapılardır. $\mathrm{Bu}$ nedenle birden fazla bağlantıları ve etkileşim yolları bulunmaktadır. Siyaset bilimi, yönetilenlerin yetkilerinin yönetenlere devredilmesi ve bunların karşılıklı olan ilişkilerini incelemektedir (Tortop vd., 2012, s.23). Bürokrasi-siyaset ilişkisi üzerine üç farklı yaklaşım ileri sürülmüştür. İlk yaklaşım genel olarak kabul gören bir yaklaşımdır. İlk yaklaşıma göre siyaset uygulanacak politikaları belirlerken, bürokrasi bu politikaları uygulamakta görevli tutulmaktadır. Bu yaklaşıma göre bütün rejimlerde, bürokrasi ve bürokratlar üzerinde siyasetin denetimi söz konusudur. İkinci yaklaşım, bürokrasiye daha farklı roller atfetmektedir. İlk yaklaşımda bürokrasinin siyasi rolü olmadığı belirtilirken, ikinci yaklaşıma göre bürokrasinin idari rolü olduğu kadar siyasi rolü de bulunmaktadır. İkinci yaklaşıma göre bürokrasi durmaksızın artan toplumsal talepleri karş1layacak usulleri geliştirerek, belirli zamanlarda değişen siyasi otoriteden daha avantajlıdır. Üçüncü yaklaşım ise bürokratların siyasi otorite karşısında daha özgür bir şekilde hareket etmesi ve bu doğrultuda yetki ve görev alanlarının 
tanınmasını ifade etmektedir. Bu yaklaşım, siyasi otoritenin keyfi tutumundan ve adaletsiz yönetimden yönetilenleri korumasını ve verimli, etkin bir yönetim sağlamak adına bürokrasinin üst kurullar oluşturmasını, siyasal denetim ve baskısından uzak bir yapının kurulmasını ileri sürmektedir (Durgun, 2002, ss.84-85).

Woodrow Wilson "İdarenin Incelenmesi” başl1kl1 makalesinde, yönetimin siyasetten ayrı bir alan olarak ele alınması gerekliliğini belirtmiştir. Makalede, kamu yönetimi kamu hukukunun sistematik olarak uygulanış biçimi şeklinde yer alan ifade neticesinde kamu yönetiminin ayrı bir inceleme alanı olması zorunluluğu vurgulanmıştır (Wilson, 1887). Wilson, kamu bürokrasisi için bir kimlik arayışına girerek, yönetimin siyasetten hem kuramsal hem de pratik açıdan özerkliği sağlamaya yönelik çalışmıştır. Wilson'a göre yönetim bilimi siyaset biliminden ayrı olarak şekillenmesi neticesinde yönetim bilimi kendi alanındaki sorunlara çözümler getirebilecektir. Böylece sorumluluk bilincine sahip memurların oluşturduğu ve liyakate dayalı bir bürokratik yapı şekillenecektir (Özer, 2019, ss. 22-23). Frank Goodnow da Wilson'u destekleyerek, yönetim ve siyasetin sınırlarının net bir biçimde belirlenip birbirinden ayrı ele alınması gerekliliğini vurgulamıştır. 1927 senesinde Willioughby tarafından kaleme alınan "Principles of Public Administration" (Kamu Yönetiminin İlkeleri) adlı eserde, yönetimin siyasetten ayrı bir şekilde ele alınması desteklenmiştir. Klasik kamu yönetimi anlayış1, yönetim-siyaset ayrımına dayanmaktadır (Ayhan ve İrdem, 2018, ss. 5-6). Buna karşın siyaset-yönetim ayrımını reddeden yaklaşım da bulunmaktadır. Bu yaklaşıma göre bürokratlar, siyaset yapım aşamasının ve yönetişimin içinde bulunan bir faktördür. Bürokratlarla siyasetçiler arasında görülen ilişkinin hiyerarşiye dayanmadığı, akıcı ve dahili bir niteliğe sahip olduğu belirtilmektedir (Ery1lmaz, 2013, s.110).

20. yüzyılın sonlarında siyaset yönetim ilişkisi, depolitize devlet anlayışı ekseninde yönetimin siyasi otoritenin müdahalesinde uzak, etkinliği temel unsur olarak ele alan ve yöneticilerin keyfi tutumlarını engelleyen bir yapı içindedir. $\mathrm{Bu}$ amaç doğrultusunda siyasetçilerin, yöneten kesimin sahip olduğu sınırlı sorumluluğundan faydalanmaları ve yetkilerini bir şekilde kötüye kullanmaları ihtimaline karşı bir tedbir alınmaktadır. Aynı zamanda yönetimin etkinliğini ve verimliliğini artırmak adına üst düzey bürokratlar yetkilendirilmektir. Siyasi otoritenin bazı uzmanlık ve teknik alanlar ile ekonomi idaresinde etkisinin azaltılması üst kurullar olarak örgütlenmiş tarafsız bir bürokratik yapılanmayı gerekli k1lmaktadır (Güler, 2016, s. 358). 
Siyasal sistemin bir alt sistemi olarak yönetim sistemi kabul edilebilir. Siyasal sistemde devlet kuruluşlarının yanında yasama, yürütme organları, siyasi partiler, dinsel kuruluşlar gibi büyük yapılar da bulunmaktadır. Siyasal sistem içinde yer alan yönetim sistemi, diğer alt sistemler ile iç içe olduğu gibi bazen de ayrı bir yapıda ele alınabilir. Siyasal sistem ile kamu teşkilatı arasında çift yönlü olan bir ilişki bulunmaktadır (Fedayi, 2007, s. 46). Kamu politikalarının tespiti ve uygulama aşaması ele alındığında bürokrasi ve siyasetin iç içe bir görünümde olduğu net bir şekilde anlaşılmaktadır. Yüksek makamlarda kararlar verilirken, seçeneklerin net bir şekilde belirlenmesinde idareciler hoşnutsuz davransalar dahi konunun özelliği nedeniyle politik yargıların verilmesi mecburi tutulmuştur. $\mathrm{Bu}$ nedenle bürokratik otoritenin işleyişi siyasal süreçten ayrılmamaktadır (Acar, 2002, s. 7).

Yönetim bilimi alanında çalışmalar yürüten sosyal bilimcilerin çoğunluğu tarafından benimsenen bir gerçek vardır. Bu gerçek, büyük kuruluşlarda politika belirleme fonksiyonları ile yönetim fonksiyonlarının birbirinden ayrılmasının zor olduğudur. Büyük bir örgüt olarak nitelendirilen devlet için de aynı ifadeler belirtilmektedir. Devlet idaresinde siyasal süreç ile bürokrasinin üstlendiği yürütme faaliyetlerinin hukuki açıdan ayrımı basit olsa dahi hayata geçirilme aşamasında zor olmaktadır. Böylece bürokratik otoritenin işleyişinin siyasal süreçten ayrı bir şekilde incelenemeyeceği ifade edilmektedir (Şaylan, 1986, s.32). Salt yönetim veya salt siyasi süreç var olamaz. Siyaset ve yönetim birlikte hareket eden iki alandır. Bu durum yüksek mevkilere terfi ve azil faaliyetlerinde açık bir şekilde kendini göstermektedir. Weber'in ifade etmiş olduğu siyasetten kopuk ve tarafsız bürokrasi yapısının da imkânsız olduğu görülmektedir. Böylece siyaset ile bürokrasinin birbirinden bağımsız ve soyut bir şekilde ele alınmayacağı belirtilmektedir. Bürokrasi ve siyaset kavramlarının işleyiş açısından bağlantılı bir yapıda oldukları için aralarında gerilim ve çatışma da meydana gelmektedir. Seçim ile göreve gelen siyasileri ile atama yolu ile göreve gelen bürokratlar arasında nitelikleri ekseninde bir etkileşim oluşmaktadır (İzci ve Bozdoğan, 2016, s. 36-37).

Peters, kamu yönetimini anlamak amacıyla, bürokrasinin üç farklı düzeyde ele alınabileceğini savunmuştur. Bu üç farklı düzeyin siyasi, idari ve toplumsal kültür olduğunu ifade etmiştir. Belirtilen üç düzeyin bürokrasinin işleyişini önemli düzeyde etkilediğini belirterek, bürokrasinin bu üç düzeyden ayrı bir şekilde ele alınamayacağını vurgulamıştır (Peter, 2001, s. 35). Dreyfus da bir devletteki yönetimin tasarlanma şeklinin, o devletin siyasi kültüründen bağımsız bir yapıda olamayacağını savunmuştur. Ayrıca bürokrasinin, yürütme aracılığıyla anlam kazanan siyasi bir iradenin uygulama aracı olduğunu belirtmiştir. İdari personelin devletin hizmetinde olduğunu ve devletin yönetenlerden ayrı olarak düşünülmesi 
gerekliliğini vurgulamıştır. Tarihsel açıdan bakıldığında idarenin siyasi mücadelelerden doğduğunu da belirtmiştir (Demir, 2011a, s. 156).

Bürokrasi-siyaset ilişkisinde aktörlerin üstlendiği görevler ekseninde ideal işleyiş unsurlarından çok ayrı faaliyet gösterdikleri ifade edilmektedir. Bürokrasi ve siyaset arasında görülen sorunların kökeninde bu aktörlerin sahip oldukları farklı güç kaynakları bulunmaktadır. Siyasi otorite tarafından alınan kararları hayata geçiren bürokratın konumu, etkin değil gibi görünse de aslında bürokratın devlet idaresinin işleyişinin bir getirisi olarak pek çok imkânı bulunmaktadır. Öte yandan halkın iradesi ile halkı yönetme görevine sahip olan siyasetçiler, görünenin tersine bürokratlardan daha edilgen bir konumda yer alabilmektedirler (Aksan ve Çelik, 2011, s. 8).

Bürokrasinin siyasete etkisi olduğu kadar siyasetin de bürokrasiye etkisi bulunmaktadır. Bürokrasinin siyaset üzerindeki etkisi özellikle siyasi aktörlerin halkın desteğini alamadığı zamanlarda ortaya çıkmaktadır. Yüksek oranda halk desteğini alan siyasi aktörlerin olduğu dönemlerde ise bürokrasinin siyaset üzerindeki etkisi zayıf kalmaktadır. Etkinin fazla olduğu dönemlerde, siyasi kararların bürokratikleştiği görülmektedir. Siyasetin bürokratikleşmesi ile birlikte bürokrasi, hedeflemiş olduğu politikaları siyasetçiler aracılığıyla gerçekleştirmektedir. $\mathrm{Bu}$ doğrultuda siyasi aktörlerin özgür bir şekilde karar aldıkları düşünülse de karar alma süreçlerinde bürokratların belirlediği sınırlar içerisinde kaldıkları söylenebilmektedir. Bu ilişkinin somutlaştırılmış örneği olarak üst düzey kamu idarecileri ve bakan-bürokrat ilişkisi gösterilmektedir. Siyasetin bürokrasi üzerindeki etkisi de bürokrasinin siyasallaşması olarak ifade edilmektedir. Siyasi otorite güçlü bir halk desteği aldığı zaman bürokrasinin etki alanına büyük ölçüde girmektedir. Böylece siyasi otorite politikasının, bürokrasinin hedefleri arasında yer alması ve bazı siyasi çıkarların kamu çıkarından üstün duruma gelmesi gibi neticelerle sonuçlanmaktadır. Bu durum önemli bürokratik ilkelerin değersizleşmesine neden olmaktadır. Liyakat, adalet gibi kamu yönetimine dair ilkelerin önemsizleşmeye başladığı görülmektedir. Bürokrasi ile siyaset arasında var olan ilişki, her iki aktörün birbirine müdahale etme ve etkileme gücü, sahip oldukları güç kaynaklarına dayanmaktadır. Her iki aktörün sahip olduğu güç kaynakları ile birbirlerine karşı özerk sahalar meydana getirmekte ve bu kaynaklar ile karşılıklı baskı kurulmaktadır (Uçman, 2014, ss.73-80).

Bürokrasinin siyaset karşısında pek çok güç kaynağı bulunmaktadır. En önemli güç kaynağı, uzmanlığa ve bilgiye sahip olmasıdır. Devlet fonksiyonlarının yürütülmesi adına gerekli enformasyonun büyük bir bölümü bürokrasiden sağlanmaktadır. Siyasi otorite bir husus 
hakkında karar almak için bürokrasinin sahip olduğu uzmanlık ve bilgiye gerek duymaktadır. Bürokrasinin ikinci güç kaynağı karar alma gücüdür. Bürokrasinin birçok hususta siyasi otoriteden daha hızlı bir şekilde karar aldığı ve uyguladığı görülmektedir. Bürokrasinin siyasi desteği bulunması da güç kaynakları arasında yer almaktadır. Çıkar gruplarının kendi faydaları doğrultusunda bürokrasiyi yönlendirme çabaları bu iki aktör arasında bağlantının oluşmasını sağlamaktadır. Bürokrasinin güç kaynaklarından bir diğeri ise karar alma sürecinde siyasi etkilerden uzak yalnızca uzmanlığın gerekleri doğrultusunda hareket edebilme yetkisidir. Kararların uygulama aşamasında bütün unsurlar üzerinde hakimiyet kurabilen tek güç bürokrasidir. Siyasi otorite karar alma aşamasında dahi bürokratlarına danışarak hareket etmektedir. Kamu planlamasında, ulusal ekonominin düzenlemesinde veya ulusal politikaların tespitinde bürokrasinin başat rol oynaması da güç kaynakları arasında sıralanmaktadır. Planların entegrasyonunda siyasi otoritenin olumsuz etkisi olacağı düşüncesi nedeniyle bu alanda bürokrasi önemli rol oynamaktadır. Bürokrasinin bir diğer güç kaynağı ise daimî ve istikrarlı statülerinin bulunmasıdır. Siyasi güçler değişebilir ancak bürokrasi, kamu hizmetlerinin sunumunda aksamalar oluşmadan sürekli hizmet etmektedir (Öztürk, 2017, ss.134-145).

Bürokrasinin siyaset karşısında güç kaynağı olduğu gibi siyasi otoritenin de bürokrasi karşısında pek çok güç kaynağı bulunmaktadır. Siyasetin en önemli güç kaynağı, meşru otoriteyi temsil etmesidir. Bürokrasiyi yönetme, denetleme, işletme gibi önemli eylemler siyasi otoritenin elindedir. Siyasetin elinde olan bu güç ise anayasa ve kanunlara dayanmaktadır. Bütçe yapma ve vergi koyma yetkisi siyasetin elindedir. Bürokrasi görevlerini uygulamak ve yürütebilmek için bütçeye ihtiyaç duyar ve siyasi kurumların bu bütçeyi sağlaması adına ikna etme çabası göstermektedir. Siyasi otoritenin bir diğer güç kaynağı ise halktır. Halkı temsil eden siyasi otorite, çeşitli araçlar yoluyla kamuoyunda bürokrasiye karşı etkin bir kazanım sağlayabilir. Siyasi kurumlar, bürokrasi dışında etkin bir bilgi kaynağı oluşturabilir. Geliştirilen bu bilgi kaynakları ve uzman personel kadrolarıyla birlikte bürokrasinin uzmanlık ve bilgi tekeli sona ermiş olmaktadır (Eryılmaz, 2017, ss. 270-271). 


\section{Başkanlık Sistemi ve Cumhurbaşkanlığı Hükümet Sistemi}

\subsection{Başkanlık Sisteminin Genel Özellikleri}

Başkanlık sistemi, en eski yazılı anayasa olarak nitelendirilen 1787 tarihli Amerika Birleşik Devletleri Anayasası'nın onayladığı bir yönetim sistemidir. Parlamenter sistemde olduğu gibi tarihi bir gelişmenin sonucu olmayıp, 1787 yılında toplanan Kurucu Meclisin uzun görüşmeler neticesinde oluşan bir hükümet şeklidir. Başkanlık sistemi oluşturulurken öncelikle doktrini yapılmış daha sonrasında uygulamaya geçilmiştir. Amerika'da 17. Yüzyılda 13 İngiliz sömürge eyaleti kurulmuştur. Bu sömürge eyaletlerinin birlikte hareket ederek, 1774 yılında ilan ettikleri Haklar Beyannamesinde bazı haklarının olduğunu belirtmişlerdir. Bu dönemde olaylar büyüyerek, iç çatışmalar yaşanmıştır. 1776 yılında İstiklal Beyannamesi yayımlayarak, Amerika'da bulunan 13 koloni halkı olaylar nedeniyle istiklallerini ilan edip bağımsız birer devlet haline gelmişlerdir. Sömürge eyaletleri, 1777 yılında bir konfederasyon idaresi ve Kongre kurmuştur. 1787 yılında ise kabul edilen Federal Anayasa ile birlikte başkanlık sistemi kabul edilmiştir (Kuzu, 2015, ss.19-20).

Başkanlık sisteminde yürütme, tek başlıdır. Genel politikanın sorumlusu ve geniş yetki alanına sahip başkan, genel oyla fakat iki dereceli bir seçimle seçilmektedir. Ancak halk tarafından doğrudan seçildiği kabul etmektedir. Başkanı seçmek için seçilen ikinci seçmenler, emredici vekalet uyarınca kendi partilerinin başkan ve başkan yardımcısı adaylarına oy vermektedir. Yürütme yetkisini elinde bulunduran başkan, bu yetkisini direkt olarak kullanabildiği gibi başkan yardımcıları (sekreterleri) aracılığı ile dolaylı bir şekilde de kullanabilir. Başkanlık sisteminde başkan yardımcıları, başkanın belirlemiş olduğu politikayı uygulamak ile görevli tutulmaktadır. Başkan yardımcıların atamaları veya görevden uzaklaştırılmaları, Senato'nun onayı ile başkan tarafından yapılır. Başkan, yürütme yetkisini bir hükümet başkanı ile paylaşmamaktadır. Bu nedenle siyasi ve hukuki yönden yürütmenin asıl yetkilisi başkandır. Başkan yardımcıları, meclis üyesi olamaz ve meclis görüşmelerine katılamazlar. Böylece başkan yardımcılarının, meclise karşı siyasi yönden sorumlulukları bulunmazken, doğrudan başkana karşı sorumludurlar. Başkan, yardımcıları ile birlikte karar alabilir. Ancak başkan yardımcıları ile yürütülen toplantılar birer danışma niteliğinde kalmakta çünkü karar alma aşamasında son söz sahibi başkan olmaktadır (Teziç, 2012, ss. 505-506).

Başkan hem devletin hem de hükümetin başıdır. Bu nedenle başkan geniş yetkilere sahiptir. Büyük yetkilerinin yanında önemli görevleri de bulunmaktadır. Siyasi sorumluluğu bulunmayan başkanın cezai sorumluluğu vardır. Kongre meclis soruşturması dışında 
başkanının görevine son verememektedir. Başkanın cezai sorumluluğun işletilebilmesi için Temsilciler Meclisi'nin en az üçte biri tarafından suçlanması gerekmektedir. Vatana ihanet, zimmetine para geçirme gibi ağır suçlar nedeniyle başkanın cezai sorumluluğu işletilebilmektedir. Başkanın siyasi sorumsuzluğu bulunduğu için bu ağır suçlar dışında herhangi bir neden ile başkan azledilememektedir (Tosun ve Tosun, 1999, ss. 62-63). Halkın seçimi ile göreve gelen başkanın, siyasi sorumluluğu yoktur. Başkanlık sisteminde dengeleme ve denetleme sisteminde kongreye verilen yetkiler neticesinde başkanın dolaylı olarak siyasi açıdan denetlediği belirtilmektedir. Başkan, kanunların yürütülmesi ve nizamı oluşturma hususunda yetkilerini tek başına kullanabilmektedir. Kanun yapımı aşamasında doğrudan katılmadığı zamanlarda da bu kanunların uygulamasına dair ayrıntıları belirleme yetkisi bulunmaktadır (Gençcan, 1997, ss.19-20).

Başkanlık sisteminin temelinde güçlü bir yürütme organı bulunmaktadır. Başkan devletin sembolü ve temsilcisidir. Başkan çeşitli çevrelerden gelen ziyaretçileri kabul eder ve resmî törenlere katılır. Başkan, yürütme erkinin tamamını şahsında somutlaştırarak temsil etmektedir. Başkan yürütme gücünü elinde tutar ancak bu yetkiler yalnızca yürütme ile sınırlı tutulmaktadır. Başkan, iç politikayı ana hatlarıyla belirler ve dış politikaya yön verir. Başkan Senato'nun onayı ile milletlerarası antlaşma yapabilir. Başkan, en yüksek askeri komutandır. $\mathrm{Bu}$ yetki sembolik değildir. Kongre savaş ilan etme yetkisini elinde bulundursa da silahlı kuvvetlerin nasıl, nerede, ne zaman kullanılacağına dair kararları başkan vermektedir. Başkan bu yetkiyi tek başına kullanmaktadır. Aynı zamanda Senato'nun onayı ile askeri mevkilere atamalar yapma yetkisi de bulunmaktadır (Yanık, 1997, ss.41-43).

Başkanlık sisteminde yasam organı başkanı güvensizlik oyu ile düşüremediği gibi başkan da yasama organını feshedememektedir. Yürütme ve yasama erkleri birbirinin varlıklarını sonlandıramaz. Bunun nedeni olarak başkanlık sisteminin benimsemiş olduğu sert kuvvetler ayrılığı gösterilmektedir. Sert kuvvetler ayrılığı neticesinde yürütme ve yasama erkleri birbirinden bağımsız olarak faaliyet göstermektedir. Bu durumun bir diğer sonucu olarak, aynı kişinin aynı anda hem yürütme hem de yasama organında yer almaması gösterilebilir. Her iki erk arasında görülen mutlak ayrılık, yürütme organının yasama organının çalışmalarına müdahale etmemesini sağlamaktadır. Başkan ve sekreterler, yasama organının toplantılarına katılamaz ve fikir beyan edemezler. Başkan, kanun teklif edemez (Gözler, 2012, s. 234). 
Yasama organı olan Kongre, Senato ve Temsilciler Meclisi şeklinde iki meclisten oluşmaktadır. Kongre'nin yetki alanı yasama ile sınırlıdır. Yasa yapma yetkisi Temsilciler Meclisi ile Senato'nun anlaşması ile gerçekleşmektedir. Temsilciler Meclisi, mali yönlü yasaların önerisini yapmaktadır. Senato ise Temsilciler Meclisi tarafından verilen mali nitelikli yasa tasarılarının onaylanıp onaylanmamasında tamamen serbesttir. Temsilciler Meclisi, şartlar karşılandığı takdirde devlet başkanını seçmektedir. Başkanlık seçiminde adayların ikinci seçmenlerin mutlak oy çoğunluğunu sağlayamaması neticesinde, Temsilciler Meclisi en yüksek oyu alan adaylar arasında başkanı seçer (Tosun ve Tosun, 1999, ss. 67-69). Senato'nun, başkanın atadığı bakanların ve üst düzey kamu görevlilerinin atamalarını onaylama yetkisi bulunmaktadır. Aynı zamanda Senato'nun sahip olduğu yetkiler arasında ikinci seçmenlerin seçememesi durumunda en fazla oyu alan iki aday arasından başkan yardımcısı seçme ve başkanın yaptığı anlaşmaları çoğunluk ile onaylama yetkileri de yer almaktadır (Kuzu, 2015, s. $35)$.

\subsection{Cumhurbaşkanlığı Hükümet Sisteminin Genel Özellikleri}

Türkiye, parlamenter sistemi benimsediği dönemde yaşamış olduğu yönetsel krizler nedeniyle alternatif hükümet sistemi arayışına girmiştir. Türkiye'de hükümet sisteminden kaynaklı yaşanan kaos döngüsüne dair pek çok değişiklik gerçekleşmiş ancak Özal'dan sonra her cumhurbaşkanı döneminde mevcut hükümet sisteminin doğurduğu sorunlar hep tartışılagelmiştir. Bilhassa 2007 senesinde cumhurbaşkanı seçimi sırasında yaşanan problemler ve Anayasa Mahkemesi’nin “367 Kararı” yürütme organında tıkanıkların yaşanmasına neden olmuştur. Bu olaylar akabinde öncelikle toplanma ve karar yeter sayısı için anayasa değişikliği kararı alınmış ve cumhurbaşkanının seçilme usulünde değişiklikler yapılmıştır. 2014 senesinde gerçekleşen cumhurbaşkanlığı seçiminde Recep Tayyip Erdoğan halk tarafından seçilmiş ilk cumhurbaşkanı olarak göreve gelmiştir (Akıncı, 2019, s. 50). Türkiye'de 2011 seçimlerinden sonra yeni anayasa konusu üzerinde somut adımlar atılmaya başlanmıştır. $\mathrm{Bu}$ dönemde Uzlaşma Komisyonu kurulmuş ancak yeni bir anayasa hazırlanamamıştır. 1 Kasım 2015 seçimleri akabinde yeni anayasa yapma umutları, Komisyonun üçüncü toplantısında dağılması ile birlikte sona ermiştir. Ancak 15 Temmuz darbe girişiminin ardından tekrar yeni anayasa çalışmaları başlamıştır. Bu doğrultuda somut adımlar atılmış ve Milliyetçi Hareket Partisi (MHP) Genel Başkanı Devlet Bahçeli’den büyük destek görmüştür. AK Parti harekete geçerek, başkanlık sistemini içeren Anayasa değişikliği önerisini hazırlamıştır. AK Parti ile MHP arasındaki müzakereler neticesinde meydana getirilen 22 maddelik Anayasa değişikliği teklifi TBMM Başkanlığına sunulmuştur. Anayasa değişikliği teklifinin temel gayesi ise saf bir 
parlamenter sistem niteliği taşımayan 1982 Anayasası'ndaki yapının sona erdirilmesi ve başkanlık sistemine geçilmesi olarak ifade edilmektedir. Teklifin sunulmasındaki temel gerekçelerinde mevcut yönetsel sistemin istikrarlı bir yapı sağlamadığı ve iktidar üzerinde bürokratik vesayetin olduğu belirtilmiştir. Teklifin başkanlık sisteminin temel niteliklerini taşıdığı ancak yürütmenin başı olarak Başkan yerine Cumhurbaşkanı ifadesi kullanıldığı görülmektedir. Teklifte yürütme tek başl1, doğrudan halk tarafından seçildiği, Cumhurbaşkanı ve TBMM'ye karşılıklı olarak görevden alma imkânı tanındığı belirtilmiştir (SETA, 2016, ss.5$6)$.

Cumhurbaşkanlığg hükümet sisteminin öncelikle yönetsel krizlere son verilmesi, toplumsal ve siyasi kutuplaşmaların azaltılması, demokrasinin benimsenmesi, işlevsiz yapıda olan bürokrasinin etkin hale getirilmesi ve her türlü vesayete karşı mücadele edilmesi yönünde hedefleri bulunduğu belirtilmektedir. Yeni sistem, başkanlık sistemi veya Türk tipi başkanlık sistemi gibi adlarla ifade edilse de Türkiye'nin sosyal, kültürel, siyasi, ekonomik ve demokratik anlayışının bir ürünü olarak meydana gelmiştir. Bu nedenle yeni sistemin ABD tipi veya Latin Amerika ülkelerinde uygulanan başkanlık sistemi ile aynı tarzda olduğu düşünülemez (Akıncı, 2019, s. 51).

Cumhurbaşkanlığı hükümet sistemi ile birlikte hayata geçirilen yeniliklerden bazıları şu şekilde sıralanabilir: Yürütme organı tek başlı olup, yürütme organının sahip olduğu yetki ve görevler cumhurbaşkanı şahsında toplanmaktadır. Cumhurbaşkanının partisiyle olan bağı devam etmektedir. Cumhurbaşkanı yasamadan bağımsı bir şekilde cumhurbaşkanı yardımcılarını, bakanları ve üst düzey bürokratları atama yetkisi bulunmaktadır. Yürütme organının cezai ve siyasi sorumluluğu bulunmaktadır. Yasama faaliyetleri, yürütmeden bağımsız meclis tarafından gerçekleşmektedir. Yasama ve yürütme organlarının her birisi seçimlerin yenilenmesi kararını alabilmektedir. Yasama ve yürütme organlarının seçimleri birlikte aynı gün gerçekleşmektedir. Seçmen, yasama ve yürütme erklerini doğrudan seçmektedir. Yürütme organı, vesayet odaklarını engelleyerek demokrasinin benimsenmesini sağlamaktadır (Eren ve Akınc1, 2018, ss. 49-50). Parlamenter sistemde yürütmenin meclise karş1 sorumlu olması neticesinde uygulanan gensoru mekanizması Cumhurbaşkanlığı hükümet sisteminde terk edilmiş ve cumhurbaşkanın sorumluluğun halka karşı olduğu belirtilmiştir. Aynı zamanda cumhurbaşkanlığı hükümet sisteminde, parlamenter sistemde yetkili ancak sorumsuz cumhurbaşkanının yerine hem siyaseten hem de diğer hususlarda sorumlu olması öngörülmüştür (Güler, 2018, s.312). 
Cumhurbaşkanın yetki, görev, nitelikleri, seçimi ve diğer hususlar Türkiye Cumhuriyeti Anayasası'nın 8, 101, 104, 105 ve 106'ncı maddelerinde ifade edilmektedir. Cumhurbaşkanının yürütme yetkisi ve görevi Anayasanın 8. maddesinde şu şekilde yer verilmektedir: Yürütme yetkisi ve görevi, Cumhurbaşkanı tarafindan, Anayasaya ve kanunlara uygun olarak kullanılır ve yerine getirilir. Anayasanın 101. maddesinde Cumhurbaşkanının kırk yaşını doldurmuş, yükseköğrenim yapmış, milletvekili seçilme yeterliliğine sahip Türk vatandaşları arasından, doğrudan halk tarafından seçileceği yer almaktadır. Cumhurbaşkanının görev süresi beş yıldır. Bir kimse en fazla iki defa Cumhurbaşkanı seçilebilir. Genel oyla yapılacak seçimde, geçerli oyların salt çoğunluğunu alan aday, Cumhurbaşkanı seçilir. İlk oylamada bu çoğunluk sağlanamazsa, bu oylamayı izleyen ikinci pazar günü ikinci oylama yapılır. Bu oylamaya, ilk oylamada en çok oy almış iki aday katılır ve geçerli oyların çoğunluğunu alan aday, Cumhurbaşkanı seçilir. Anayasanın 104. maddesinde yer alan Cumhurbaşkanının görev ve yetkileri ise kısaca şu şekilde belirtilebilir: Cumhurbaşkanı devletin olup, yürütme yetkisine sahiptir. Cumhurbaşkanı, devlet başkanı sıfatıyla Türkiye Cumhuriyeti'ni ve Türk Milletinin birliğini temsil eder. Kanunları yayımlar. Kanunları tekrar görüşülmek üzere TBMM'ye geri gönderir. Cumhurbaşkanı yardımcıları ile bakanları atar ve görevlerine son verir. Üst kademe kamu yöneticilerini atar, görevlerine son verir ve bunların atanmalarına ilişkin usul ve esasları Cumhurbaşkanlığı kararnamesiyle düzenler. Milletlerarası Andlaşmaları onaylar ve yayımlar. Anayasa değişikliklerine ilişkin kanunları gerekli gördüğü takdirde halkoyuna sunar. Milli güvenlik politikalarını belirler ve gerekli tedbirleri alır. TBMM adına Türk Silahlı Kuvvetlerinin Başkomutanlığını temsil eder. Anayasanın 105. maddesinde Cumhurbaşkanı hakkında, bir suç işlediği iddiasıyla TBMM üye tam sayısının salt çoğunluğunun vereceği önergeyle soruşturma açılması istenebileceği yer almaktadır. Anayasanın 106. maddesinde ise Cumhurbaşkanı, seçildikten sonra bir veya daha fazla Cumhurbaşkanı yardımcısı atayabilir, Cumhurbaşkanlığı makamının herhangi bir nedenle boşalması halinde, kırk beş gün içinde Cumhurbaşkanı seçimi yapılabilir ve Cumhurbaşkanı yardımcıları ve bakanlar, milletvekili seçilme yeterliliğine sahip olanlar arasından Cumhurbaşkanı tarafindan atanır ve görevden alınır ifadelerine yer verilmektedir.

Yeni sistem ile Cumhurbaşkanlığı Teşkilatı, Cumhurbaşkanlığı Kararnamesi'nde ifade edildiği gibi Cumhurbaşkanlığı makamı, Cumhurbaşkanı Yardımcıları, İdari İşler Başkanlığı, Bakanlıklar, Politika Kurulları ve Ofislerden meydana gelmektedir. Cumhurbaşkanlığı teşkilatında yer alan Cumhurbaşkanlığı Ofisleri Dijital Dönüşüm Ofisi, Finans Ofisi, İnsan Kaynakları Ofisi ve Yatırım Ofisi olmak üzere dört farklı alandaki ofisi kapsamaktadır. Ofisler 
Cumhurbaşkanlığına bağlı, özel bütçeli, idari ve mali özelliği bulunan ve kamu tüzel kişiliğine haiz yapılardır. Bir diğer oluşum ise dokuz farklı alanda kurulan Cumhurbaşkanlığı Politika Kurullarıdır. Yeni sistemde Başbakanlığın kapatılması, bazı bakanlıklarının kaldırılması, bazı bakanlıklarının da birleştirilmesi sonucunda 24 olan bakanlık sayısı 16'ya düşürülerek yeni bir yapılanma getirilmiştir (Özer, vd. 2019, ss. 218-219). Bakanlıkların yeni sistemdeki konumuyla birlikte müsteşarlık makamı kaldırılmış ve idari işler başkanlığı yürütme erkinde önemli bir konuma yükselmiştir. Ayrıca bu makamın, ABD’de başkana en yakın isimlerden olan Beyaz Saray Sekreteri ile aynı niteliğe sahip olduğu vurgulanmaktadır (Küçük, 2020, s. 49).

Cumhurbaşkanlığg hükümet sisteminde yürütme ve yasama arasında sert ayrılık uygulanmaktadır. Bakan ve başkan yardımcısı olarak atanan milletvekilleri, görevlerinden istifa etmek zorundadır. Yürütme ve yasama arasında personel ve görev ayrılığı ortaya konulmuşken, yarg1 bağımsızlığ1 yönünden aynı durum söz konusu olduğu söylenememektedir. Cumhurbaşkanı Hakimler ve Savcılar Kurulu üyelerinin dördünü bizzat atamakta, Adalet Bakanı bu kurulun başkanlığını yürütmekte ve Adalet Bakanlığı Müsteşarı bu kurula doğal üye olarak katılmaktadır. Geriye kalan yedi üye ise meclis tarafından atanmaktadır. $\mathrm{Bu}$ durumda Cumhurbaşkanının partisi ile mecliste çoğunluğu sağlayan parti aynı olursa Kurul üyelerinin büyük çoğunluğunun siyasi iktidarın tercih ettiği isimlerden meydana gelebileceği söylenebilir (Öztürk, 2019, s. 61).

Cumhurbaşkanlığı hükümet sisteminde yürütme organı yapısal açıdan tek kişiden oluşmaktadır. Yürütme faaliyetlerinin yerine getirilmesi aşamasında ise Cumhurbaşkanı tarafından görevlendirilen yardımcılar, bakanlar ve üst düzey yöneticiler ön plana çıkmaktadır. Sistemde yürütmenin başında bulunan Cumhurbaşkanına, kadrosunu tamamen kendi isteği doğrultusunda belirlemesi yetkisi tanınmıştır. Halkın iradesi ile seçilen cumhurbaşkanına tanınan bu imkân devlet idaresinde istikrarın ve başarının sağlanması adına gerekli görülmektedir (Aydoğdu, 2019, s. 87). Yeni sistemde yasamanın üstünlüğü kabul görmekle birlikte, yürütmenin etkisi daha fazla ön plana çıkmaktadır. Öncelikle, Cumhurbaşkanı yardımcıları ve bakanların atamasında, meclis onayı şartı öngörülmemiştir. Yeni sistemde cumhurbaşkanı ile birlikte seçim yolu ile göreve gelen bir yardımcılık makamının olmadığ görülmektedir. Cumhurbaşkanı yardımcılarının doğrudan Cumhurbaşkanı atamasına dayanıyor olması ile özel statülü bir yürütme otoritesinin sağlandığı görülmektedir (Alkan, 2018, s.145).

Yeni sistemin etkin işleyişi yönünden, otorite ve yetkinin iyi dağıtılması, farklı sektörlerin siyasi otorite karşısında özerkliğini sağlaması, hukuk devleti ilkelerinin 
benimseniyor olması, seçim barajının düşürülmesi ve demokratik bir yapılanmanın sağlanması önem arz etmektedir. Bu yapıda idarenin etkinliği, istikrarı, temsilde adalet, güçler dengesi gibi önemli etmenlerin daha kolay bir şekilde sağlanabildiği görülmektedir. Ayrıca meclisin yürütme üzerinde gücünü azaltacak ve teftişini de dengelemeye katkı sağlayabilecektir. Atamalar ve kararnamelerin meclisin onayı olmadan uygulamaya geçirebilecek yeni sistemde, kanun yapma ve gündem belirleme gücü zayıflamış bir parlamento ortaya çıkmaktadır. Meclisin özgürlükleri ve çoğulculuğu koruma yönünden de kendini daha güçsüz bir konuma gelecektir. Bu durumda siyasi veya toplumsal azınlıkların dışlanması ve otoriter idari yapıya yönelme olasılığı yükselecektir (Gül, vd. 2017, s.118).Yeni sistem siyasi ve hukuki açıdan pek çok değişikliği beraberinde getirmesiyle birlikte bürokrasinin rasyonel, etkin ve verimli yönetilmesi adına önemli adımların atıldığı da görülmektedir (Çalışkan ve Önder, 2017, s. 578).

\section{Başkanlık ve Cumhurbaşkanlığı Hükümet Sistemlerinde Bürokrasi- Siyaset İlişkisi}

\subsection{Başkanlık Sisteminde Bürokrasi- Siyaset İlişkisi}

Başkanlık sistemini uygulayan en iyi örnek ABD’dir. Amerikan bürokrasisi ile siyaseti arasındaki ilişkinin ele alınıp değerlendirmesi neticesinde başkanlık sisteminde görülen bürokrasi- siyaset ilişkisi de ortaya konulmuş olacaktır. Amerikan bürokrasisinin siyaset ile ilişkisi incelendiğinde geçmişte uygulanan "spoil sistem” nedeniyle, siyasete karşı önemli ölçüde güçsüz durumda olduğu belirtilmektedir (Tataroğlu, 2016, s. 77). Günümüzde ise bu sistem terk edilerek, liyakat sistemi benimsenmektedir. Liyakat sistemi ile kamu personel sistemi kariyer ve daimî bir yapıya sahip olmuştur. ABD’de seçimi kazanan yeni başkan göreve geldiği vakit yalnızca birkaç bakanı atamakla kalmayarak, kamu görevlileri açısından da bir değişime gitmektedir. Bu durumun yeni başkanın yürütme üzerindeki etkinliğini artırdığ yönünde düşünceler hakimdir. Yönetimin değişmesiyle birlikte yaklaşı üç bin kişinin görevini bıraktığı ifade edilmektedir. Görevi bırakan kişilerin büyük çoğunluğu yeni başkan ile göreve devam etmemeyi uygun bulmaktadır. Bu durumun ise siyasi aktörler ile bürokratların uyumlu bir şekilde çalışmalarını sağladığı ve böylece etkinliğin ve verimliliğin artacağı savunulmaktadır (Özer ve Özmen, 2017, s. 27).

Amerikan sistemine göre iki tür kamu görevlisi vardır. Bunlardan ilki sınıflandırılmış veya daimî hizmetlerdir. Bu görevlere personel alımında liyakat ilkesi uygulanarak, atamalarda ve yükselme işlemlerinde siyaset etkin değildir. İkinci tür ise sınıflandırma dışında yer alan istisnai görevlilerdir. Bu tür kamu görevlileri politika belirleme aşamasına dahil olan, güven 
pozisyonlarından meydana gelen ve siyasal tercihli atamalar ile göreve gelen üst düzey yöneticilerdir (Belet, 2008, s. 62).

ABD'de yürütme erkinde üst düzey yönetici atama sorumluluğu Başkan ve Kongre arasında paylaştırılmıştır. Üst düzey yönetici atama işlemlerinde öncelikle Başkan potansiyel kişiyi seçerek aday göstermekte, Kongre ise adayı değerlendirmekte ve onay verilirse Başkan da resmi atamayı gerçekleştirmektedir (Sobacı ve Köseoğlu, 2018, s. 27). Başkanlık sisteminde kamu personelinin sadakati, sadece iktidar partisine ve başkana değil, ayrıca meclise karşı da bulunmaktadır. Meclis, bütçe görüşmelerinde kamu personelini değerlendirmektedir. Hatta parlamenter sistemde bürokratların siyasi aktörlere karşı "Yes, Minister:Emret Bakanım" ifadesinin kullanıldığı belirtilirken, başkanlık sisteminde ise bürokratların "Yes, Congressman: Emret Kongre üyesi” ifadesini kullandığ 1 vurgulanmıştır. Başkanlık sisteminde üst düzey kamu görevlilerinin sorumluluğu, farklı şekillerde sağlanmaktadır. Kamu yöneticileri, bakanlık içindeki üstlerine karşı sorumlu ve üstler vasıtasıyla da başkana karşı sorumluluk taşırlar. Aynı zamanda doğrudan Kongredeki komitelere ve alt komisyonlara karşı sorumlulukları bulunmaktadır (Eryılmaz, 2013, ss. 131-132).

Federal düzeyde atama yetkisi başkanın elindedir. Ancak atama yaparken Senato'nun onayını alması gerekmektedir. Bu durumda da başkan, Senato'nun onayını alabilecek isimleri göreve getirmiş olmaktadır. Başkanın sahip olduğu üst düzey yöneticileri atama yetkisi ile birlikte federal devletin idari politikalarına şekil vermektedir. Senato'nun bu aşamada sahip olduğu temel rol ise başkanın önerdiği kişileri onaylama veya onaylamama şeklindedir. Anayasa atama hususunda başkana açık ve net bir şekilde yetki vermesine rağmen görevden alma hususunda net bir düzenleme yoktur (Öztürk, 2018, s. 214).

Başarılı bir başkanlık için politika danışmanlığı ve uygulaması aşamasında donanımlı kişilerin mevcudiyetinin sağlanması gerekmektedir. Başkanın nitelikli bir takıma sahip olması politikaların amacına uygun bir şekilde gerçekleşmesi açısından önem arz etmektedir. Üst düzey yöneticilerin kamuoyunda bilgili ve kabiliyetli olarak değerlendirilirse idarenin önerilerine destek artabilir. Üst düzey yöneticiler başkanın yönetiminin sembolleri olarak nitelendirilir. Böylece başkanın en önemli kararları arasında üst düzey yönetici atama kararları da yer almaktadır (Riddlesperger and King, 1986, s. 691).

ABD'de bürokrasinin siyaset tarafından kontrol altında tutulması geçmişten günümüze gelen bir temel yapıdır. Bu nedenle bürokrasinin kontrol altında olması önemli bir düşüncedir. Bürokrasini kontrolünde meydana gelebilecek bir eksiklik nedeniyle bürokratik bir iktidar şekli 
oluşacağı kaygısı genel kabul görmektedir. Siyasetin bürokrasi üzerinde kontrolünün olmadığ1 zaman bürokrasi, Kongre ve başkanın yönergelerini göz ardı ederek, kendi kuralları dışında başka bir norma karşı sorumluluk duymayacağı vurgulanmıştır. Bürokrasi bu yapıya dönüşür ise vatandaşları da hizmet sunulan efendiler değil, yönetilecek bir nesne olarak görülmeye başlanacaktır. Bürokrasinin Kongre tarafından kontrolü, bürokratik yapıların vatandaşa karşı daha fazla sorumlu hizmet üretmesi için şekillenmiştir (Tataroğlu, 2006, ss. 104-105). Kongre, meclislerinde bulunan komisyonlar vasitasıyla bürokrasinin yürüttüğü hizmetleri denetler. $\mathrm{Bu}$ denetimin amacı ise hizmetlerin etkinliğini ortaya koymak olduğu belirtilmektedir (Tosun ve Tosun, 1999, s. 69). Bürokrasi üzerinde mevcut olan Kongre'nin kontrolü üç anlama dayanmaktadır. Öncelikle Kongre, bürokrasiyi kendi uzantısı olan bir yapı olarak görürken, işin asıl sahibi ise kendisi olduğunu düşünmektedir. İkinci olarak bürokrasinin işlemlerinde meydana gelebilecek bir yanlış uygulamadan haberdar olduğunda müdahale edebilme yetkisi bulunmaktadır. Son olarak ise Kongre, bürokrasinin yapısal koşullarını yasama işlemleri ile ortaya koyar ve devamlılığı sağlamaktadır. Ancak Kongre'nin bürokrasi üzerinde sonsuz kontrol hakkına sahip olmadığı belirtilmesi gerekmektedir. Zamanla Kongre'nin sahip olduğu bu yetkisinde zayıflama gözlenmektedir (Tataroğlu, 2006, s.106).

Başkanlık sisteminde bürokrasinin denetlenmesi hususunda iki kurumun rekabet halinde olduğu belirtilmektedir. Bu nedenle bürokrasi, Kongre ve başkana karşı sorumlu olmakta ve denetime tabi tutulmaktadır. $\mathrm{Bu}$ yapı bürokrasi siyaset ilişki yönünden incelendiğinde bürokrasiye bir kurumu diğer kuruma karşı kullanma olanağı sunması dışında daimî ve uzun süreli faydalar sağlama hususunda yetersiz kalmaktadır (Belet, 2008, s. 64).

ABD'de başkanın kamu yönetimi üzerindeki denetim mekanizması, kamu görevlilerinin eylemlerini, seçilmiş başkanın makamı vasıtasıyla halka karşı sorumlu tutulması şeklinde düzenlenmiştir. Başkanlık; bütçedeki belirleyici rolü, reorganizasyon yetkisi, kumanda gücü, liderlik vb. uygulamalarla, bürokrasiyi başkanın denetimi altına alma veya bürokrasiyi bu isteklerin yerine getirilmesi için motive etme imkanına sahiptir. Fayda-maliyet analizleri veya rasyonelleşmiş bütçe sistemleri olarak yapılan reformlar, bürokratik yeteneği arttırma teknikleri olarak sunulmasına rağmen, gerçekte genellikle başkanlık kontrol gücünü arttırmaya yarayan yöntemlerdir. Bürokrasi üzerindeki başkanlık kontrolünün düğüm noktası, onun idaresinde yer alan bütün bürokratik eylemlerden sorumlu tutulmasıdır. Seçilmiş başkanın kamu bürokrasisinin tümüne egemen olması iradesi açıç̧a ortaya konmuş olsa da Amerikan kamuoyunda, başkanlığın bürokratik direniş ve hantallığa karşı mücadelesini yetersiz bulan değerlendirmeler sıklıkla duyulmaktadır. Günümüz ABD başkanları, kendi başkanlık alanlarına 
giren bütün bürokratik işlem ve eylemler üzerinde yetkili değildir. Onların bürokrasiyi daha fazla denetim altına alma ve verimli hale getirme çabaları, azalarak da olsa devam etme eğilimindedir (Tataroğlu, 2016, ss.79-80). Aynı zamanda başkanlık sisteminde başkanın bürokrasi üzerindeki etkisi daima aynı düzeyde seyretmemektedir. Başkanın sahip olduğu güce göre bürokrasi üzerindeki etkisinin değiştiği görülmektedir. Amerikan sisteminde güçlü liderlerin olduğu dönemlerde bürokrasinin de güçlü ve etkili olduğu belirtilmektedir (Öztürk, 2018, ss. 223-226).

Amerikan siyasi sisteminde siyasi atamaların en etkin bürokratik denetim yapısı olduğu kabul görmektedir. $\mathrm{Bu}$ sistemin bütçe kısıntıları, meclis uygulamaları, meclisten iletilen mesajlar ve kamunun yeniden yapılanması gibi klasik usullere göre daha etkili olduğu belirtilmektedir. Seçilmiş otoriteler, bürokratik davranışı programlı metotlar ile biçimlendirebilirler. 1978 tarihli Kamu Hizmeti Reform Yasası'nda devlet başkanının üst düzey kamu yöneticilerini kendi politikasına uygun olarak seçebileceği yer almaktadır. Aynı zamanda bürokratik süreci hafifleştirme amacıyla başka kurumlara transfer yapma veya iş yükünü azaltma gibi işlemler de yapabilmektedir. Bu yasa ile birlikte devlet başkanının bürokrasiyi kontrol etmek için siyasi atamalar yapmasının yolu açılmıştır. Siyasi açıdan tarafsız ve bağımsız kamu görevlileri kavramının, yüz yıllık bir geçmişi bulunmakta ve siyasi yönden sadakatli kamu görevlileri talebi çok daha eski ve güçlü bir düşünce yapısı sunmaktadır. Yürütme erki kendi programlarının uygulanması adına kendilerine uygun olan kamu görevlilerini göreve getirirler. Görevden alma veya atama işlemleri, siyasi otoritenin bürokrasi üzerindeki kontrol mekanizmasıdır. Böylece ideoloji ve sadakat, diğer unsurlardan daha öncelikli bir hale gelmektedir (Demir, 2011b, s.80).

\subsection{Cumhurbaşkanlığı Hükümet Sisteminde Bürokrasi- Siyaset İlişkisi}

Türkiye'de Cumhurbaşkanlığı hükümet sistemi öncesinde bürokrasinin konumu, uygulayıcı rolünün çok ötesindedir. Yeni sistemden önce kamu politikalarının oluşturulmasında ve uygulanmasında bürokrasi etkili bir konumdadır. Bürokrasi, siyasi otoriteye rağmen ayrı iktidar gücü kullanan bir konuma gelmiştir. Yeni sistem ile birlikte Osmanlı Devleti'nden Türkiye Cumhuriyeti'ne miras kalan bürokratik yönetim geleneğinde değişim ve dönüşüm yapılması öngörülmektedir (Kırışık ve Öztürk, 2020, s. 179). Türkiye Cumhuriyeti'nde uygulan eski hükümet sisteminin geçmişine bakıldığında 1980 yılı itibariyle yürütme erki güçlendirilmiş olsa dahi bürokrasinin sahip olduğu gücü tam anlamıyla kıramadığı görülmektedir. Yeni hükümet sistemi ile bürokrasinin hizmet sunumunda görevden kaçınabilme yollarının ve 
sorumluluktan kaçılması için sunulan gerekçelerin minimuma indirilmesi amaçlanmaktadır (Kutlu ve Kahraman, 2017, s.18). Türkiye'nin siyasi tarihi ele alındığında bilhassa koalisyonlu yılların getirdiği kadrolaşma sistemi Türk bürokrasisi yapısında üst düzey yöneticilerin atamalarında siyasi otoritenin kendi ideolojilerini benimseyen isimleri seçtiği atama usulünün uygulandığı görülmektedir. Bu durum siyaset ile bürokrasi arasında yakınlık veya zıtlık bağlamında ilişkilerin olduğunu göstermektedir (Esen ve Kalağan, 2020, s. 273).

Cumhurbaşkanlığı hükümet sistemi ile birlikte demokratikleşme adı altında "gardiyan bürokrasi" niteliğinde ve siyasi otoriteye dayanan bürokratik yapının dönüşümü adına önemli adımlar atılması hedeflenmiştir. Bu adımlar bürokrasi ve siyasi otorite arasındaki dikey işlevsel farklılaşmayı benimseyen bir zihniyet dönüşümünü kapsamaktadır. Yeni sistemle birlikte yayımlanan kararnameler, bürokrasinin daha etkin faaliyet göstermesi için kullanılan önemli araçlar olarak görülmektedir (Sobac1, 2018).

Türkiye'de etkin, verimli ve daha denetlenebilir bir bürokratik yapının sağlanması için gerekli olan yönetsel sistemin başkanlık sistemi olduğu yönünde tartışmalar yaşanmaktaydı. $\mathrm{Bu}$ tartışmalar neticesinde Cumhurbaşkanlığı hükümet sistemi hayata geçirilmiştir. Yeni sistemin başkanlık sistemi ile benzer niteliklere sahip olmasıyla birlikte bürokrasiyi daha verimli hale dönüştürme ve etkin denetiminin sağlanabilmesi için gerekli olan yapıyı oluşturduğu düşünülmektedir. Ayrıca yeni sistemde kamu politikalarının oluşturulmasında bürokratik oligarşinin engellenmesi için önemli adımların atıldığ 44). Bilhassa Cumhurbaşkanı Recep Tayyip Erdoğan'ın sıç̧a askeri, yargı ve sivil bürokrasiden rahatsızlığını dile getirdiği bilinmektedir. Cumhurbaşkanı Recep Tayyip Erdoğan, siyaset bürokrasi ilişkisine değinerek bürokratik yapılanmada görülen bozulmalara ve siyasallaşmış bürokrasiye son verilmesi gerekliliğini vurgulamıştır. Bu doğrultuda yeni sistemde, bürokraside üst düzey yönetici atamalarının usul, ilke ve kuralları Cumhurbaşkanlığı Kararnamesi ile düzenlenmiştir (Esen ve Kalağan, 2020, s.273).

Yeni sistemde cumhurbaşkanı eğitim, sağlık, ekonomi ve tarım gibi pek çok konuda kamu politikalarını kabinesinin katkıları ile ve bizzat atadığı üst düzey kamu görevlileri eliyle politikaların gerçekleşmesini takip edecektir. Türkiye'de üst düzey kamu görevlilerinin yalnızca kamu politikalarının uygulamasında değil politikaların oluşturulmasında katkı sağladığ1 göz önünde bulundurulduğunda, üst düzey yöneticilerin yönetsel ve hukuki sorumluluklarının dışında belirlenen hedeflere ulaşma yönünden de cumhurbaşkanına karşı sorumlu olduğu görülmektedir (Sobacı ve Köseoğlu, 2018, ss. 43-44). 
Yeni sistemde üst düzey kamu görevlilerinin kadro oluşturma aşamasında yasa yerine Cumhurbaşkanlığı Kararnameleri geçerli olmaktadır. 3 sayılı Cumhurbaşkanlığı Kararnamesi ile cumhurbaşkanı ile gelip cumhurbaşkanı ile gidecek olan üst kademe kamu yöneticileri belirlenmiştir. Kararnamede yer alan I Sayılı Cetvel'de bulunanların görev süresi cumhurbaşkanının süresi ile sınırlı tutulmakta ve listede bulunan kadrolara cumhurbaşkanı doğrudan atama yapmaktadır. Bu cetvelde yer alanlara örnek verilirse; Diyanet İşleri Başkanı, MİT Başkanı, TOKİ Başkanı, Cumhurbaşkanlığı Ofis Başkanları, SGK Başkanı, Valiler, Büyükelçiler, Bakan Yardımcıları, Gelir İdaresi Başkanı, Bakanlıkların Teftiş Kurulu, Denetim Hizmetleri Başkanları ile Diğer Kurul Başkanları, Genel Müdürler vb. II Sayılı Cetvel'de yer alanların atanmaları ise doğrudan Cumhurbaşkanı tarafından yapılmamaktadır. Başka merciler tarafindan yapılan atamalar Cumhurbaşkanı tarafından onaylanmaktadır. $\mathrm{Bu}$ cetvelde yer alanlara örnek verilirse; TOKİ Başkan Yardımcıları, Sayıştay Savcıları, Genel Müdür Yardımcıları, Bakanlık Daire Başkanları, Polis Akademisi Başkanı, Bakanlık Müfettişleri, I. Hukuk Müşavirleri, Vali Yardımcıları ve Kaymakamlar vb. (Resmî Gazete, 2018, Sayı 30474).

Türkiye'de uzun süre devam eden parlamenter sisteminde güçler ayrılığının net bir şekilde olmaması ve her daim güçlü bir iktidarın kurulamaması nedeniyle bürokrasi, devlet idaresinde kendine daha fazla alan açmıştır. Aynı zamanda toplum ve bürokrasi üzerinde gerçek anlamda kontrol oluşturabilecek siyasi otoritenin, liderlik niteliklerine barındırmadaki eksiklikler de sistemin olumsuz yönleri olarak nitelendirilmektedir. Cumhurbaşkanlığı Hükümet Sistemi ile birlikte tam güçler ayrılığg olması ve yürütmenin tek elde toplanması neticesinde bürokrasinin bir bütün olarak kontrol edilmesi sağlanmaktadır. Kamu politikalarının oluşturulması ve yürütülmesinde komuta birliğinin sağlanması ile Cumhurbaşkanının bürokrasiye dair söylem ve mesajları önemli bir yere sahip olmaktadır. Bu mesaj ve söylemlere örnek verilecek olunursa; Cumhurbaşkanının 29 Mart 2017 tarihinde şehirleşmede dikey mimari yerine yatay mimari getirilmelidir ifadesi neticesinde Çevre ve Şehircilik Bakanlığı yönetmelikle düzenleme yapıldı, cumhurbaşkanı tarafından 22 Ağustos 2017 tarihinde İl Sağlık yapılanmasında artan bürokrasi ve kadrolaşma nedeniyle yeniden yapılanması gerektiği belirtildikten sonra Sağlık Bakanlığı'nda KHK ile düzenleme yapıldı, aynı şekilde 17 Kasım 2019 tarihinde kamuda görev alan ve sosyal güvencesi bulunmayan sözleşmeli personelin sorunun çözülmesi gerektiği belirtildikten sonra Bakanlıklar konu ile ilgili kararname yayımlamıştır. Cumhurbaşkanının söylemlerinin genel anlamda toplumun uzun süre rahatsızlık duyduğu ancak bürokrasi tarafından çözüme kavuşturulmayan konular olduğu söylenebilir. Cumhurbaşkanının söylem ve mesajlarının bürokrasi sahasında hemen 
karşılık bulmasının nedeni ise yeni sistemin yürütme üzerindeki etkisinin fazla olduğunun göstergesidir (İzci ve Atmaca, 2019, ss.4529- 4531).

Cumhurbaşkanlığı Hükümet Sistemi ile birlikte Bakanlar Kurulu kaldırıldığı için bürokrasinin denetimi yetkisi Cumhurbaşkanına ait olmaktadır. Sistemde en üst yönetici Cumhurbaşkanıdır ve bürokrasiye dair yapılan bütün harcamaların ekonomik, verimli ve etkin olup olmadığı Cumhurbaşkanı tarafından incelenmektedir. Yeni sistemde tüm üniversiteler ve yerel yönetimleri de kapsayan kamu kurumlarını tümünde iş birliğiyle ve yetkili üst kurul işleyişiyle İç Denetim Koordinasyon Kurulu Cumhurbaşkanı'na bağlanmıştır. Bu durum Kamu Mali Yönetimi ve Kontrol Kanunu'nun öngördüğü iç denetimin tüm kamu kurumlarında etkin bir şekilde uygulanmasını sağlayacaktır (Akbulut ve Kaş, 2018, ss.85-86). Yeni sistemde kamu personel sisteminde yapılan değişiklikler önemli bir yere sahiptir. Bilhassa bu konuda Cumhurbaşkanına tanınan yetkiler önem arz etmektedir. Sistemin en etkili yönlerinden biri bürokrasinin kontrol altına alınması olarak değerlendirilmektedir. Güçlü bir yürütme organı ile bürokrasinin daha etkin bir şekilde denetim altına alındığı belirtilmektedir (Turan, 2018, s.78).

Başkanlık sisteminde başkan, yaklaşık yirmi bin orta ve üst düzey bürokratı atamakta ve yüksek sayıda personele sahip bürokrasinin etkin çalışabilmesi için önemli yetkiler kullanmaktadır. Bu yetki içinde atananlar başkanın görev süresiyle eş zamanlı olarak görevli olmaktadır. Aynı şekilde Türkiye'de de üst düzey bürokratların Cumhurbaşkanı ile birlikte değişmesi, bürokrasi açısından etkinliği sağlayacak bir unsur olarak görülmektedir. Ancak üst düzey bürokratların statü yönünden sözleşmeli birer personel olarak atanmasının tartış1lır bir yönünün olduğu da ifade edilmektedir. Yeni sistemde bürokrasinin daha verimli ve etkin bir şekilde faaliyet göstermesi noktasında önem arz etmektedir. Cumhurbaşkanının hem tek başına seçilen hem de güçlü bir liderlik figürü sergilemesi ile bürokrasi gün geçtikçe güçlü bir yapıya sahip olmasını sağlamaktadır (Kutlu ve Kahraman, 2017, ss. 21-22).

Cumhurbaşkanlığı hükümet sistemi yönetim açısından ele alındığında partili anlamda siyasi kimlikli Cumhurbaşkanı etrafında toplanan bir kamu bürokrasisi oluşturulduğu görülmektedir. Bu yapı yalnızca merkezi teşkilatta kurulmamıştır. Hizmet yönünden yerinden yönetim kuruluşları, uzmanlık kurumları olarak ayrı kamu tüzel kişilikleri bulunsa da işlevsel açıdan Cumhurbaşkanlığına bağlanmışlardır (Zengin, 2019, s. 21).

Yeni sistemle birlikte değişen bürokrasi ve siyaset ile olan ilişkisi üzerine farklı değerlendirmeler bulunmaktadır. Yeni sistemin cumhurbaşkanına fazla yetki tanıması neticesinde bürokratik vesayetin değil, bürokraside siyasallaşmanın ortaya çıkacağı ifade 
edilmektedir. Bürokratik vesayet gibi olumsuz sonuçlar doğurabilecek olan bu durum, siyasi otoritenin bürokrasi üzerinde kurduğu baskıdır. Bu doğrultuda yönetimin kişiselleşmesi yönünde endişeler ifade edilmektedir (Mercimek, 2018, ss.145-146). Yeni sistemde cumhurbaşkanı, atamaların çoğunluğunu bizzat gerçekleştirmektedir. Bu durum neticesinde cumhurbaşkanı tarafından atanan isimlerin kendilerini farklı bir yerde görmelerine neden olabilmektedir. Ayrıca partili cumhurbaşkanı tarafından atananların kendilerini cumhurbaşkanına ve halka karşı sorumlu hissetmeleri gibi partiye karşı da sorumlu hissetmesine yol açacaktır. Yeni sistemde bürokratik oligarşinin engellenmesi için önemli adımların atıldığı yönünde genel bir değerlendirme olmasına rağmen halkın gözünde atamaların siyasi olduğu düşünülecek ve bürokratik oligarşiye zemin hazırlayacaktır (Atmaca ve Günay, 2020, s.207). Cumhurbaşkanlığı Hükümet Sistemi ile birlikte özelde üst düzey kamu yöneticilerinin olması ve atamalarının halk tarafından seçilen cumhurbaşkanı tarafından gerçekleşmesi sonucunda bürokrasi, siyasetin tam merkezinde konumlanmıştır. Aynı zamanda yeni sistemde partili cumhurbaşkanının olması da bürokrasinin siyasetin alanına tam anlamıyla girmesine neden olmuştur. Bu durum neticesinde olumsuz sonuçların doğacağını ifade eden fikirler olduğu gibi aksini düşünen ve belirten ifadeler de bulunmaktadır. Üst düzey kamu yöneticilerinin atama ve görevden alma işlemlerinde siyasi parti ilişkileri, siyasi ideolojilerinin etkin olması, hizmet sunumunda siyasileşmesine sebep olarak parti-devlet bütünleşmesine neden olabileceği belirtilmektedir. Bu durum neticesinde de siyasi parti yakınlıkları bürokrasisiyaset ayrımını yok edeceği ifade edilmektedir. Aynı zamanda üst düzey yöneticilerinin yasa ile değil de Cumhurbaşkanı Kararnamesi ile atanıyor olması geniş bir takdir yetkisi sağlamaktadır. Bu geniş takdir yetkisi de üst düzey kamu yöneticilerinin kolaylıkla atanması veya görevden alınmasına neden olmakta ve istikrarsız bir bürokratik yapıya yol açmaktadır (Eren ve Saitoğlu, 2021, ss. 324-325).

Cumhurbaşkanlığı hükümet sisteminde bürokratik yapının konumu ve siyasi otorite ile olan ilişkisi üzerine olumsuz yorumlar yapıldığı gibi olumlu yorumlar da yapılmaktadır. Yeni sistemde üst düzey kamu görevlilerinin cumhurbaşkanı tarafından atanıp görevden alınıyor olması sayesinde bürokratik değişimin kolay gerçekleşebileceği belirtilmektedir. Böylece bürokrasinin kökleşmesi engellenecek, sisteme egemen olamayacak ve bürokrasinin sivil iradeye bağglılığı sağlanacaktır. Aynı zamanda yürütmenin tek elde toplanması ve meşruiyetini halktan almasıyla bürokraside vesayetçi yapının engelleneceği ifade edilmektedir (Karatepe vd., 2017, s. 56). Doğrudan halk tarafından seçilen cumhurbaşkanının bürokrasideki üst düzey yöneticileri ataması neticesinde bürokrasi- siyaset odaklı krizlerin yaşanılmayacağı 
belirtilmektedir. Aynı zamanda Cumhurbaşkanının kamu politikası oluşturma aşamasında üst düzey yöneticilerine danışması ile bürokrasi-siyaset problemlerine son verilebileceği ifade edilmektedir (Eren ve Saitoğlu, 2021, s. 324).

\section{Sonuç}

Devlet olgusunun ortaya çıkışı kadim zamanlara dayanmaktadır. Devlet, büyük gücün temsilcisi olarak siyaset biliminin merkezinde yer almaktadır. Devlet olgusu ile birlikte devleti kimin veya hangi merciinin yöneteceği sorunu ortaya çıkmıştır. Bu doğrultuda seçimle göreve gelen yönetme hakkını elinde bulunduran siyasi otorite ile kamu hizmetlerinin yürütülmesini sağlayan bürokratik yapı meydana gelmiştir. Devletin kimin yöneteceği sorusu üzerine oluşturulan siyaset ile bürokrasi kurumunun karşılıklı ilişkisi de bu süreçle birlikte başlamıştır. Siyaset-bürokrasi ilişkisi, her iki aktörün zamanla yaşadığı dönüşüm ve atfedilen değerle birlikte değişkenlik göstermiştir. Bilhassa 20. yüzyılın son çeyreğinde görülen kamu yönetiminde paradigma değişimi neticesinde siyaset-bürokrasi ilişkisi farklı boyutlara ulaşmıştır. Bu süreçte bürokrasinin gücü ve konumu tartış1lırken, siyasi otoritenin bürokrasiyi etkisi altına alan ve etkisini artıran bir yapıya büründüğü görülmektedir.

Kamu yönetimi disiplininde uzun süreler tartışılan önemli konulardan biri de siyasetbürokrasi ayrımıdır. Kamu yönetimi ve siyasi otoritenin bir bütünün parçaları olduğu düşüncesi neticesinde siyasi otorite politika belirlerken, bürokrasi ise bu kararları uygulamaktadır. Bu nedenle iki bilim dalı arasında keskin bir ayrım yapmak imkânsızdır. Siyasetçilerin ve bürokratların ortak bir amacı bulunmakta ve bu doğrultuda siyasi otorite ile bürokrasi arasında etkileşimin olmadığını söylemek gerçekçi olmamaktadır.

Weber'in ideal tip bürokrasisi, siyaset-bürokrasi ayrımını savunmuştur. Weber de dahil olmakla birlikte pek çok siyaset bilimci, bürokratların siyasal süreçteki konumu konusunda farklı fikirler ileri sürmüş ve uzun süre siyasetin dışında pasif bürokrasi kavramı ele alınmıştır. $\mathrm{Bu}$ doğrultuda bürokratlar, siyasi tercihleri bulunmayan ve siyasi otorite tarafından her görevi objektif bir şekilde yerine getiren bir yönetim makinasıydı. İleri sürülen görüşün temelinde Weber'in ideal tip bürokrasisi yer almaktadır. Ancak mevcut bürokratik yapının hiçbir ideal tipe uymadığı görülmektedir. Bürokratların iki şekilde siyasal sürece dahil oldukları belirtilmektedir. İlk olarak bürokratların siyasal eğilimleri olduğu ifade edilirken, ikinci olarak da bürokratik yapıda belirli örgütsel düzeyin üstünde siyasal niteliğin olduğu belirtilmektedir. Bu doğrultuda bürokratların apolitik kişiler olmadığı söylenebilir (Şaylan,1986, ss. 33-34). 
Bürokrasinin temel işlevi kamu hizmeti sunmaktır. Ancak bürokrasinin bu temel gayesinden uzaklaşarak siyasi otorite üzerinde etki kurduğu da görülmektedir. Bunu yaparken sahip olduğu güç kaynaklarını kullanmaktadır. Aynı şekilde siyasi otorite de bürokrasi üzerinde kontrolü ve etkiyi sağlamak için pek çok faaliyette bulunmaktadır. Bu doğrultuda siyasetin bürokratikleştiği ve bürokrasinin de siyasallaştığı görülmektedir. Demokratik ve başarılı bir idare için ilgili tüm aktörlerin etkin ve uyum içinde çalışmalıdır. Siyasi otorite ile bürokrasinin karşılıklı olarak uyum içerisinde faaliyet göstermesi, devlet mekanizmasının etkin bir şekilde işlemesi için önem arz etmektedir.

Devletlerin benimsemiş oldukları siyasal rejimler neticesinde bürokratik yapı ve işleyişinde önemli farklılıklar doğmaktadır. Bu farklılık bürokratik yapıda olduğu gibi siyasetbürokrasi ilişkisinde de net bir şekilde görülmektedir. Siyasal rejimler arasında demokrasi temelli olan hükümet sistemleri arasında dahi siyaset-bürokrasi bağlamında pek çok farklılığın olduğu belirtilmektedir. Farklı unsurları barındıran hükümet sistemleri arasında siyasetbürokrasi ilişkisini karşılaştırmaya yönelik çalışmalar bulunurken, benzer nitelikleri benimseyen iki hükümet sistemi arasında siyaset-bürokrasi ilişkisinin incelendiği ve karşılaştırıldığı çalışmaların azlığı dikkat çekmektedir. Bu doğrultuda çalışmanın ana temasını oluşturan Başkanlık Sistemi ile Türk tipi Başkanlık Sistemi olarak nitelendirilen Cumhurbaşkanlığı Hükümet Sisteminde siyaset-bürokrasi ilişkisine dair genel değerlendirme şu şekilde yapılabilir:

Gelişmiş devletler içerisinde siyasi otoritenin bürokrasi üzerinde en fazla kontrolü sağladığ 1 devlet Başkanlık sistemi ile yönetilen ABD’dir. ABD tarihine bakıldığında bürokratik yönetim geleneği olmadığı gibi bürokrasinin siyasi otoriteye karşı söz sahibi olmadığı da görülmektedir. Çünkü ABD'de bürokrasinin siyasi otoritenin yetkilerine karşı herhangi bir müdahalesi olabilecek bir sistem bulunmamaktadır. Bürokrasi üzerinde etkin kontrolü sağlayan kanalların, diğer devletlere göre daha başarılı olduğu belirtilmektedir. Başkanlık sisteminde yürütme erkinin sahip olduğu yetki ve güçler neticesinde yönetimde istikrarsızlığın görülmesi düşük bir olasılıktır. $\mathrm{Bu}$ nedenle bürokrasinin en tepesinde bulunan siyasi patron iktidarda kalma kaygısı yaşamayarak, etkin bir yapı kurabilmektedir.

ABD’de görülen bürokrasi üzerindeki etkin denetimin en temel sebebi olarak bürokratik bir iktidarın kurulacağı kaygısı gösterilebilir. Bu nedenle bürokrasi yalnızca başkanın denetiminde olmayarak, Kongre tarafından da sıkı kontrol içerisindedir. Bilhassa yapılan siyasi atamalarla birlikte bürokrasi denetim altına alınmaktadır. Ancak ABD'de siyasi otoritenin 
bürokrasi üzerindeki etkisinin her dönem aynı seyirde olmadı̆̆ı ifade edilmektedir. Başkanın sahip olduğu liderlik sıfatı ve özellikleri doğrultusunda bürokrasi ile ilişkisi şekillenmektedir.

Başkanın değişmesiyle birlikte binlerce kamu personeli görevini bırakmakta ve yeni yönetimle çalışmak istemediklerini belirtmektedir. Bu nedenle Başkanlık sisteminde siyasi otorite ile bürokrasi arasında büyük oranda uyumun sağlandığı ve bu iki aktör arasında çatışmaların minimum düzeyde olduğu söylenebilmektedir. Ancak Başkanlık sisteminde üst düzey kamu görevlilerinin atamasında Başkan tek başına hareket edememektedir. $\mathrm{Bu}$ sorumluluk Başkan ile Senato arasında paylaştırılmıştır. Başkan için üst düzey kamu görevlileri önem arz etmektedir. Çünkü bu mercii hem başkanı temsil etmekte hem de başkan bürokrasi üzerindeki etkin yetkisini bu kadrolar aracılığı ile sağlamaktadır.

Türk siyasi hayatında siyaset-bürokrasi ilişkisi dönemsel açıdan farklılıklar göstermiştir. Tek parti iktidarı döneminde bürokrasi devleti yöneten bir konumda ve siyasi otoriteyi kontrol altına alan bir durumdayken, çok partili dönemde bürokrasinin gücünü kırmak için önemli eylemler hayata geçirilmiştir. 1960 darbesi ile birlikte bürokrasi, eski gücünü tekrar kazanmıştır. 1980'i yıllarda gündeme gelen yeni sağ düşüncesi ekseninde bürokrasinin konumu tartışılmış ve etki alanının azaltılması ele alınmıştır. Ancak bu süreçte istenilen sonuçlara ulaşılamamış ve bürokrasi ile siyasi otorite arasında güç dengesizliği görülmüştür. 2002 yılı ve sonrasında Türk kamu yönetimine dair gerçekleşen reformlarla birlikte bürokratik dönüşüm yaşanmış ve siyasi otorite, bürokrasinin gücünü en az seviyeye çekmek için adımlar atmıştır. Bu çalışmaların ne düzeyde başarılı olduğu tartışılır çünkü her ne kadar bürokratik dönüşüme dair çalışmalar yapılsa da güçlü bir direnç ile karşılaşılmaktadır. Türkiye tarihinde sivil ve askeri kanadıyla bürokrasi, siyasi otorite üzerinde vesayet makamı olarak çalıştığı görülmektedir.

Cumhurbaşkanlığg Hükümet Sistemi ile birlikte hâkim olan bürokratik yapıda değişim ve dönüşümün hayata geçirilmesi öngörülmüştür. Etkin bir kamu yönetimi, dengeli siyasetbürokrasi ilişkisi, siyasallaşmış bürokratik yapıya son verilmesi gibi önem arz eden konular üzerinde durularak, yeni sistemle birlikte bu hususların gerçekleşeceği ifade edilmiştir.

Yeni sistemde güçlü bir yürütme organının olması nedeniyle bürokrasi etkin bir şekilde denetlenmektedir. Cumhurbaşkanı yürütme gücünü tek başına elinde bulundurduğu için bürokrasi denetimi farklı makamlar tarafından değil bizzat cumhurbaşkanınca yerine getirilmektedir. Aynı zamanda yeni sistemle birlikte üst düzey kamu görevlilerinin Cumhurbaşkanı Kararnamesi ile atanıyor olması, siyasi otoritenin bürokrasiyi kontrol altında 
tutması açısından önemli bir araç olarak görülebilmektedir. Cumhurbaşkanının bizzat yapmış olduğu söylem ve mesajların bürokrasi kanadında çok hızlı bir şekilde etkisini göstermekte ve harekete geçirmektedir. Bu durum siyasi otoritenin bürokrasi üzerindeki etkisini açık bir şekilde ortaya koymaktadır.

Yeni sistemde cumhurbaşkanının bürokrasi üzerindeki etkisi net bir şsekilde belirtilmiştir. $\mathrm{Bu}$ durumu eleştirenler olduğu gibi olumu açıdan yorumlayanlar da bulunmaktadır. Yeni sistemde cumhurbaşkanının siyasi parti mensubu olması nedeniyle cumhurbaşkanının bürokrasiye yönelik etkin denetimi ve üst düzey kamu görevlilerini ataması nedeniyle kamu bürokrasisinin siyasallaşacağı ifade edilmektedir. Aynı zamanda bu durumun devlet idaresinde bürokratik vesayeti ortadan kaldıracağına dair görüşler de bulunmaktadır.

Başkanlık Sistemi ile Cumhurbaşkanlığı Hükümet Sisteminin siyaset-bürokrasi ilişkisi ekseninde kıyaslandığında pek çok benzer noktaların olduğu görülmektedir. Her iki hükümet sisteminde güçlü yürütme erki olması nedeniyle siyasi otoritenin bürokrasi üzerindeki etkisi oldukça güçlüdür. Bürokrasinin denetimi hususunda da benzer özelliklerin olduğu söylenebilir. Siyaset-bürokrasi ilişkisinin temelinde bir güç mücadelesi bulunmakta ve iki aktör arasında hangisinin daha güçlü ve etkin olduğu ortaya konulmaktadır. Çalışmada incelenen hükümet sistemlerindeki siyaset-bürokrasi ilişkisi, siyasi otoritenin bürokrasi üzerinde kurmuş olduğu güç ve etki üzerine şekillenmektedir. İki hükümet sistemi arasında görülen net farkl1lık ise üst düzey kamu görevlilerinin atama usulünde görülmektedir.

Cumhurbaşkanlığı Hükümet Sisteminde yürütme branşındaki tüm üst düzey kamu görevlileri cumhurbaşkanı tarafından atanmakta ve görevden alınmaktadır. Yürütme dışındaki üst düzey memurlar ise kanunlarda ifade edilen şekil koşullarına uygun olarak yine cumhurbaşkanı tarafından atama yapılmaktadır. Ancak bu kişilerin cumhurbaşkanı tarafından görevden alınıp alınamayacağı belirtilmemiştir. Aynı durum ABD’de de görülmektedir. Türkiye'de yeni sistemle birlikte cumhurbaşkanın atayacağı kamu personeli yüzdesi ABD’de uygulanan civardadır. Cumhurbaşkanı tarafından yapılan atamaların yaklaşık olarak tüm kamu görevlilerin \%2 civarında bir oranda olduğu söylenebilir. Türkiye ve ABD’de yapılan bu tür atamalar, bürokrasinin siyasi otorite üzerindeki etkisinin kırılması açısından önem arz etmektedir (Öztürk, 2018, s. 241).

Siyasi atamalar her ne kadar siyasetin bürokratikleşmesini engellese de bürokratik yapının etkili ve verimli bir yönetim kurmamasına sebep olmaktadır. Bu düzen her iki hükümet 
sisteminde görülmektedir. Liyakat temelli bürokrasinin kurulması için gerekli olan yasal düzenlemelerin hayata geçirilmesi gerekmektedir.

\section{Kaynakça}

Acar, A. (2002). Yönetim-siyaset ilişkisinde kamuda personel politikaları. Selçuk Üniversitesi Sosyal Bilimler Enstitüsü Dergisi, 7, 5-14.

Akbulut, N. ve Kaş, O. (2018). Cumhurbaşkanlığı yönetim sisteminde kamu denetimi ve iç denetimin yeri. Denetişim Dergisi, 8 (18), 77- 87.

Akçakaya, M. (2016). Bürokrasi kuramları ve Türk kamu yönetiminde bürokratik sorunlar. Gazi Üniversitesi İktisadi ve İdari Bilimler Fakültesi Dergisi, 18(3), 669-694.

Akıncı, B. (2019). Cumhurbaşkanlı̆̆ hükümet sistemi sisteme yönelik tartışmalar ve çözüm önerileri. Ankara: Nobel Bilimsel Eserler.

Akman, E. (2019). Cumhurbaşkanlığı hükümet sisteminde kamu politikası aktörleri. Paradoks Ekonomi, Sosyoloji ve Politika Dergisi, 15(1), 35-54.

Aksan, G. ve Çelik, Ö. (2011). Gerilim ve uzlaşma: Demokrasi ekseninde bürokrasi ve siyaset ilişkisi üzerine bir değerlendirme. Selçuk Üniversitesi Sosyal Bilimler Enstitüsü Dergisi, 25, 110 .

Alkan, H. (2018). Cumhurbaşkanlığ 1 sisteminin kurumsal özellikleri ve demokratikleşme sürecine olası etkileri. Türkiye Illetişim Araştırmaları Dergisi, Özel Sayl, 139-153, Doi: $10.17829 /$ turcom.461355.

Akyüz, Ü.(2009). Siyaset ve ahlak. Yasama Dergisi, 11, 93-129.

Atmaca, Y. Ve Günay, M. C. (2020). Bürokratik oligarşi: Türk kamu yönetimi ekseninde bir analizi. Research Studies Anatolia Journal, 3(3), 199-210, doi: 10.33723/rs.733072.

Aydoğdu, Y. (2019). Yeni hükümet sisteminde Cumhurbaşkanlığı işlemleri. Düzce Üniversitesi Sosyal Bilimler Enstitüsü Dergisi, 9(1), 85-92.

Ayhan, U. ve İrdem, İ. (2018). Değișen yönetim paradigması, M. A. Özer ve U. Ayhan (Ed), Kamu yönetimi tartışmaları, 3-27, Ankara: Gazi Kitabevi.

Ball, A. ve Peters, G. (2007). Çă̆daş siyaset ve yönetimi, (N. Uzun, Çev.), İstanbul: Yayın Odasi.

Belet, M. S. (2008). Türk kamu yönetiminde siyaset ve bürokrasi ilişkisi: Üst Kurullar Bürokrasisi. (Yayımlanmamış Yüksek Lisans Tezi), Selçuk Üniversitesi, Konya.

Çalışkan, E. ve Önder, M. (2017). Başkanlık sistemi ve mevcut kamu kurumları üzerine olası etkiler. Uluslararası Sosyal Araştırmalar Dergisi, 10 (49), 570-578.

Çevik, H.H. (2001).Türkiye'de kamu yönetimi sorunları. Ankara: Seçkin Yayıncılık.

Çukurçayır, M. A.(2006). Yerel yönetimde değişim: bürokratik örgütten hizmet işletmesine doğru. Sayıştay Dergisi, 73, 31-49. 
Demir, F. (2011a). Bürokratik kültür. Süleyman Demirel Üniversitesi İktisadi ve İdari Bilimler Fakültesi Dergisi, 16 (2), 153-178.

Demir, F. (2011b). Bürokrasi-demokrasi ilişkisi ve bürokratların seçilmişlerce kontrolü sorunu. Yönetim ve Ekonomi: Celal Bayar Üniversitesi Íktisadi ve İdari Bilimler Fakültesi Dergisi, 18 (2), 63-84.

Durgun, D.(1992). Bürokrasi teorisi ve yönetim. Sosyal Siyaset Konferansları Dergisi, 37-38, 133-149.

Durgun, Ş. (2002), Türk kamu yönetiminde bürokratik siyaset. Gazi Üniversitesi İktisadi ve Ídari Bilimler Fakültesi Dergisi, Özel Sayl, 83-102.

Eren, V ve Akıncı, B. (2018). Yasama ve yürütme ilişkileri açısından Başkanlık sistemi İle Cumhurbaşkanlığı hükümet sisteminin karşılaştırılması. Y. Demirkaya (Ed), Cumhurbaşkanlı̆̆ hükümet sistemi kamu yönetiminde değişim, 35-70, İstanbul: Hiper Yayın.

Eren, V. ve Saitoğlu, F. (2021). Cumhurbaşkanlığı hükümet sisteminde üst düzey kamu yöneticileri. E. Akman(Ed), Farklı boyutlarıyla Cumhurbaşkanliğı hükümet sistemi, 301-328, Ankara: Nobel Yayınevi.

Ergun, T. (1997). Postmodernizm ve kamu yönetimi. Amme İdaresi Dergisi, 30 (4), 3-15.

Ergun, T. ve Polatoğlu, A. (1992). Kamu yönetimine giriş. Ankara: TODAİE Yayınları.

Ery1lmaz, B. (2013). Bürokrasi ve siyaset. İstanbul: Alfa Yayınc1lık.

Eryılmaz, B. (2017). Kamu yönetimi. Kocaeli: Umuttepe Yayınları.

Esen, E. ve Kalağan, G. (2020). Cumhurbaşkanlığg hükümet sisteminde merkezi idarenin dönüşümü. Süleyman Demirel Üniversitesi Vizyoner Dergisi, 11, 260-277, doi: $\underline{10.21076 / v i z y o n e r .754765 .}$

Fedayi, C.(2007). Siyasal sistem ve kamu örgütleri ilişkiler, sorunlar ve çözüm önerileri. Kamu Hukuku Arşivi, 10(1), 45-56.

Gençcan, Ö. U.(1997). Başkanlık rejimi. Ankara: Adil Yayınevi.

Gökçe, G., Şahin, A. ve Örselli, E. (2002). Türkiye'de siyasetin bürokrasi üzerindeki etkisi: siyasallaşma. SÜ İIBF Sosyal ve Ekonomi Araştırmalar Dergisi, 4, 45-58.

Gözler, K.(2012). Anayasa hukukunun genel esasları. Bursa: Ekin Yayıncıl1k.

Gül, H., Kamalak, İ. ve Gül, S.S. (2017). Amerikan Başkanlık ve Fransız Yarı-Başkanlık sistemleri 1şığında Türkiye'nin yeni Cumhurbaşkanlığı hükümeti sistemi. Strategic Public Management Journal, 3, Special Issue, 101-120, doi: 10.25069/spmj.343035.

Güler, T. (2016). 2000'li yıllar Türkiye'sinde siyaset bürokrasi ilişkilerinin kamu yönetimi reformları üzerinden okunması. Balıkesir Üniversitesi Sosyal Bilimler Enstitüsü Dergisi, 19 (36-1), 347-382, doi: 10.31795/baunsobed.662295.

Güler, T. (2018), Cumhurbaşkanlığı hükümet sistemi ve kamu yönetimine etkileri. Balıkesir Üniversitesi Sosyal Bilimler Enstitüsü Dergisi, 21(39), 299-322, doi: $\underline{10.31795 / \text { baunsobed.443821. }}$. 
Heywood, A. (2016). Siyaset. (B. B. Özipek, B. Seçilmişoğlu, A. Yayla ve H. Y. Başdemir, Çev.), Ankara: Adres Yayınları.

İzci, F. ve Bozdoğan, S. (2016). Türk kamu yönetiminde bir problem alanı olarak bürokrasisiyaset ilişkisi, Akademik Sosyal Araştırmalar Dergisi, 4(34), 33-46, doi: 10.16992/ASOS.6528.

İzci, F. ve Atmaca, Y. (2019). Yeni hükümet sisteminde Cumhurbaşkanının söylemlerinin bürokrasi üzerindeki etkisi. Journal of Social and Humanities Sciences Research, 6(48), 45224533, doi: 10.26450/jshsr.1698.

Kabaklı, A. (2017). Millete vurulan canlı pranga bürokrasi. İstanbul: Türk Edebiyatı Vakfi Yayınları.

Kalağan, G. (2009). 1980 sonrası geleneksel bürokratik yönetim paradigmasında değişim ve yönetsel-siyasal yeniden yapılanma arayışları. Süleyman Demirel Üniversitesi Vizyoner Dergisi, 1(1), 92-103.

Kapani, M. (2020). Politika bilimine giriş. Ankara: Serbest Akademi.

Karatepe, Ş., Alkan, H., Atar, Y., Bingöl, Y. Ve Durgun, G. B. (2017). Sorularla Cumhurbaşkanlı̆̆l sistemi. Ankara: Memur-Sen Yayınları.

Kaya, E. (2014). Siyaset devleti. Ankara Barosu Dergisi, 1, 221-243.

Kırışık, F. ve Öztürk, K. (2020). Cumhurbaşkanlığı hükümet sistemiyle kamu yönetiminin geliştirilmesi. Adalet Dergisi, 65, 167-200.

Kutlu, Ö. ve Kahraman, S. (2017). Türk Cumhurbaşkanlığı sisteminin kamu yönetimi açısından değerlendirilmesi. F. Uslu (Ed), Türk Anayasa Hukukunun Güncel Sorunlarl, 1-26, Sakarya: Beşköprü Yayınları.

Kuzu, B. (2015). Her yönü ile Başkanlık sistem., İstanbul: Babıali Kültür Yayıncılığı.

Küçük, Ü. (2020). Cumhurbaşkanliğg hükümet sisteminde merkez yerel ilişkileri ve vesayet denetimi. (Yayımlanmış Doktora Tezi), İnönü Üniversitesi, Malatya.

Mercimek, Ş. (2018). Bürokratik vesayet anlayışına Cumhurbaşkanlığı hükümet sisteminin etkisi. Uluslararası Batı Karadeniz Sosyal ve Beşeri Bilimler Dergisi, 2( 2), 131-149, doi: $\underline{10.46452 / \text { baksoder.497976. }}$.

Mises, L. V. (2018). Bürokrasi. Ankara: Liberte Yayınları.

Oktay, C. (2009). Siyaset bilimi incelemeleri. İstanbul: Alfa Yayınları.

Özer, M.A. (2013). Weber'in bürokrasisi karşısında yönetimde yeniden yapılandırma arayışları. Küresel İktisat ve Iş̧letme Çalışmaları Dergisi, 2(4), 43-57.

Özer, M.A ve Özmen, B. (2017). Parlamenter ve Başkanlık sistemleri arasında konumunu arayan bürokrasi. Strategic Public Management Journal, 3, Special Issue, 17-34, doi: 10.25069/spmj.343716.

Özer, M.A. (2018). Siyaset yönetim dikotomisi. M. A. Özer ve U. Ayhan (Ed), Kamu yönetimi tartışmaları,31-82, Ankara: Gazi Kitabevi. 
Özer, M. A. (2019). 21. yüzyılın modern yönetimi için geleceğe yön veren yönetim gurularl. Ankara: Gazi Kitabevi.

Özer, M.A., Akçakaya, M., Yaylı, H. ve Batmaz, N. Y. (2019). Kamu yönetimi klasik yapı ve süreçleri. Ankara: Gazi Kitabevi.

Öztekin, A. (2005). Yönetim bilimi. Ankara: Siyasal Kitabevi.

Öztürk, N. K.(2017). Bürokrasi-siyaset ilişkileri ve Türkiye. Ankara: Siyasal Kitabevi.

Öztürk, N. K. (2018). Amerikan Başkanlık sistemi ve bürokrasi. Y. Demirkaya(Ed), Cumhurbaşkanlı̆̆ı hükümet sistemi kamu yönetiminde değiş̧im, 199-247, İstanbul: Hiper Yayın.

Öztürk, N.K. (2019). Cumhurbaşkanlığı hükümet sisteminin temel dinamikleri. ASSAM Uluslararası Hakemli Dergi, 6 (15), 49-65.

Peters, Guy B. (2001). The politics of bureaucracy. Londra- New York: Routledge.

Riddlesperger, J.W and King, J. D. King (1986). Presidential appointments to the cabinet, executive office, and White House staff. Presidential Studies Quarterly, 16(4), 691-699.

Sobacı, M. Z. ve Köseoğlu, Ö. (2018). Cumhurbaşkanlı̆̆l hükümet sisteminde üst kademe yöneticiler. Ankara: SETA Rapor.

Şaylan, G. (1986). Türkiye’de kapitalizm bürokrasi ve siyasal ideoloji. Ankara: V Yayınları.

Tataroğlu, M. (2006). Parlamenter ve Başkanlık sistemlerinde siyasi iktidar ve bürokrasi ilişkileri ve Türkiye açısından bir değerlendirme. Yönetim ve Ekonomi: Celal Bayar Üniversitesi İktisadi ve İdari Bilimler Fakültesi Dergisi, 13(1), 97-119.

Tataroğlu, M. (2016). Yürütmede etkinlik bakımından Başkanlık sisteminin değerlendirilmesi. Ekonomi ve Yönetim Araştırmaları Dergisi, 5(1), 74-97.

Teziç, E. (2012). Anayasa hukuku. İstanbul: Beta Yayıncılık.

Tortop, N., İsbir, E. G., Aykaç, B., Yayman, H. ve Özer, M. A. (2012). Yönetim bilimi. Ankara: Nobel Kitabevi.

Tosun, G. E. ve Tosun, T. (1999). Türkiye'nin siyasal istikrar arayışı Başkanlık ve Yarı Başkanlık sistemler. İstanbul:Alfa Yayıncılık.

Turan, A. M. (2018), Türkiye'nin yeni yönetim düzeni: Cumhurbaşkanlığı hükümet sistemi. Social Sciences Research Journal, 7(3), 42-91.

Uçman, H. (2014). Türkiye'de bürokrasi ve siyaset -siyasi müsteşarlıktan Bakan Yardımcılığına. Ankara: Alter Yayıcılık.

Wilson, W. (1887). The study of administration. Political Science Quarterly, 2(2), 197-222.

Yanık, M. (1997). Başkanlık sistemi ve Türkiye'de uygulanabilirliği. İstanbul: Alfa Yayıncılık.

Yayla, A. (1998). Siyaset teorisine giriş. Siyasal Kitabevi, Ankara.

Yıldırım, M. (2010). Modernizm, postmodernizm ve kamu yönetimi. Uluslararası İnsan Bilimleri Dergisi, 7(1), 703-719. 
Zengin, O. (2019). Cumhurbaşkanlığı hükûmet sistemi ve idari yapıya etkisi. Emek Araştırma Dergisi, 10(15), 1-24.

\section{İnternet Kaynakları}

SETA (2016), 1982 Anayasası ve anayasa değişiklik teklifi karşılaştırması, SETA. Erişim tarihi: 02.07.2021, Erişim adresi: https://www.setav.org/1982-anayasasi-ve-anayasadegisiklik-teklifi-karsilastirmasi/.

Sobac1, M. Z. (2018). Yeni sistem ve üst kademe yöneticiler, Sabah Gazetesi. Erişim tarihi: 01.07.2021, Erişim adresi: https://www.sabah.com.tr/yazarlar/perspektif/mehmet-zahidsobaci/2018/07/14/yeni-sistem-ve-ust-kademe-yoneticiler.

Resmi Gazete, Üst kademe kamu yöneticileri ile kamu kurum ve kuruluşlarında atama usullerine dair Cumhurbaşkanlığı Kararnamesi, 10/7/2018, Sayı 30474. Erişm tarihi: 08.07.2021, Erişim Adresi: https://www.mevzuat.gov.tr/MevzuatMetin/19.5.3.pdf. 